\title{
Buckypaper bioelectrodes: Emerging materials for implantable and wearable biofuel cells
}

Received 00th January 20xx, Accepted 00th January 20xx

DOI: $10.1039 / \mathrm{x} 0 \mathrm{xx} 00000 \mathrm{x}$

www.rsc.org/

\author{
A. J. Gross, ${ }^{\text {a }}$ M. Holzinger ${ }^{\mathrm{a}}$ and S. Cosnier ${ }^{\mathrm{a}, *}$
}

Carbon nanotubes (CNTs) have been widely exploited for the development of enzymatic biofuel cells with sufficient power densities in the $\mu \mathrm{W}$ to $\mathrm{mW}$ range for operating low-power bioelectronics devices from renewable substrates. Buckypaper is a randomly oriented self-supporting film of carbon nanotubes, resembling an electronic paper, with excellent prospects for the construction of high performance enzymatic electrodes for use in biofuel cells. Attractive properties of buckypaper materials include large specific surface areas, high electrical conductivity, flexibility, biocompatibility, scalable production and the ability for efficient electron transfer with enzymes. Buckypapers are ideal self-supporting frameworks for enzymes and guest molecules such as metals, polymers and redox molecules, permitting the development of a wide range of catalytic bioelectrode interfaces. This review summarizes recent developments and advances of buckypaper bioelectrodes as an emerging component for body-integrated energy harvesting biodevices.

\section{Introduction}

The steady development of implantable technologies has resulted in revolutionary miniaturised medical devices including portable and subcutaneous blood glucose sensors, cardiac pacemakers, neurostimulator implants, and cochlear implants. ${ }^{1}$ Future implanted and wearable electronics with electrode interfaces as core components are eagerly anticipated including retinal implants to restore vision, ${ }^{2}$ electroceutical devices for chronic disease treatment, ${ }^{3}$ and "smart' contact lenses for wearable electrochemical sensing. ${ }^{4}$ In conjunction with wireless technologies, these devices will be interfaced with external systems such as smartphones to enable rapid access to digital healthcare data for better patient health outcomes. ${ }^{5}$ A significant challenge in realizing longlasting implantable and wearable bioelectronics devices is the development of a safe, continuous and perpetual power source. Lithium ion and alkaline batteries are the dominant power sources for bioelectronics devices. For implantable and wearable applications, batteries can be hazardous (to humans and the environment), bulky, rigid and difficult to remove and replace. ${ }^{6,7}$ For implantables, the cost of battery placement can be very high - the need for further surgical intervention(s). The search for safe, portable and eco-friendly power sources is therefore of immense interest. Energy harvesting devices which scavenge energy (kinetic, thermal, chemical energy) from the human body are potentially ideal solutions for powering implantable and wearable electronics. ${ }^{8-11}$

Biological fuel cells are emerging power sources which can generate electrical energy from chemical substrates in biological fluids using enzymes (enzymatic biofuel cells) or microorganisms (microbial biofuel cells) as the catalysts. ${ }^{1,12-15}$ These power sources offer several advantages over traditional batteries and fuel cells including the use of non-toxic and renewable biocatalysts and organic fuels. A major attraction of biofuel cells is the exotic prospect of, in theory, unlimited electricity generation from energy-rich compounds such as

a. Department of Molecular Chemistry, DCM, Univ. Grenoble Alpes, CNRS, 38000 Grenoble, France glucose and oxygen which are continuously produced in the body or consumed, for example, via metabolism and respiratory processes. Enzymatic biofuel cells are considered the more promising type of biofuel cell compared to microbial fuel cells for powering implantable and wearable applications owing in particular to their superior power densities. ${ }^{16-19}$ Microbial biofuel cells are better suited for eco-friendly power generation on a large scale over longer periods (e.g. years) for applications such as self-sustainable wastewater treatment. ${ }^{20}$ A few examples of microbial fuel cells for implantable and wearable power generation have nevertheless been reported. ${ }^{12-14}$

Enzymatic biofuel cells exploit the excellent properties of redox enzymes (oxidoreductases) such as their high substrate selectivity and specific activity per active site under physiological and ambient conditions. ${ }^{21,22}$ Unlike many chemical catalysts, enzymes are also biocompatible, environmentally benign, and can be produced on demand. The working principle of biofuel cells is based on the bioelectrocatalytic oxidation of a "fuel" (e.g. glucose) at the anode to generate electrons which are transferred to the cathode where bioelectrocatalytic reduction of the oxidant (e.g. $\mathrm{O}_{2}$ ) takes place. ${ }^{23}$ The most common enzymes for glucose oxidation are glucose oxidase (GOx) and glucose dehydrogenase (GDH). GDH enzymes are distinguished by their respective cofactors: pyrroloquinoline quinone (PQQ), nicotine adenine dinucleotide (NAD), and flavin adenine dinucleotide (FAD). For the reduction of oxygen to water at the cathode, multicopper oxidase (MCO) enzymes like laccase or bilirubin oxidase (BOx) are commonly used. ${ }^{24-27}$ One of the constant challenges in enzymatic biofuel cell research is to obtain an efficient transfer of electrons from the enzyme to the electrode (at the anode) and from the electrode to the enzyme (at the cathode). Indeed, achieving efficient electron transfer between enzymes and electrodes for bioelectrocatalysis is not so easy. Enzymes have poor natural conductivity, limited durability, and can be difficult to electrically contact owing to the enzyme's active site being buried within an insulating protein matrix. ${ }^{28,29}$ Ideally, the electrons involved in the powergenerating redox processes can be directly transferred between the electrode material and the enzyme. This type of 
electron transfer is called "direct electron transfer" (DET) and benefits from the optimal overpotential of the catalytic centre of the enzyme, leading to enhanced cell voltages. ${ }^{21}$ When DET cannot be achieved due to the vast insulating protein shell, inadequate enzyme orientation, or limiting kinetics, the use of a redox mediator as an electron shuttle between the enzyme and the electrode, called mediated electron transfer (MET), is the necessary alternative. ${ }^{29,30}$ For further information concerning enzymatic biofuel cells and electrode design we recommend the following recent reviews on the topic. ${ }^{11,23,30,31}$

There are still major issues to overcome before enzymatic biofuel cells can become competitive with batteries for lowpower applications. Major advances in bioelectrode design are required to improve the power density, voltage output and operational stability of biofuel cells. In addition to developing improved methods for the electrical wiring of enzymes, electrodes are required with properties including high surface areas, high conductivity and mechanical stability. Porous carbon materials including carbon nanotubes (CNTs) (e.g. forests, pellets, and drop-casted layers), ${ }^{32}$ graphene, ${ }^{33}$ mesoporous carbons (e.g. MgO-templated carbon ${ }^{34}$ and carbon nanoparticles), ${ }^{35}$ and carbon black (e.g. Ketjen black) ${ }^{36}$ are the most promising materials to date for bioelectrode construction owing to their attractive properties which include high surface area, porosity (nano-, micro-, and meso-), chemical stability, and conductivity. Comparisons of different nanostructured carbon materials for bioelectrocatalysis and biofuel cells may be found in recent reviews. ${ }^{11,37,38}$

An important aspect which is often overlooked in bioelectrode design is the development of porous carbon electrodes with desirable physical properties for their intended application such as size, stability and flexibility. For example, many bioelectrodes are constructed via the simple adsorption of carbon deposits on glassy carbon supports, resulting in bulky, rigid, and sometimes fragile electrodes. Such electrode ensembles are therefore not well suited for body-integrated energy applications. ${ }^{34-36,39}$ CNT pellet electrodes formed by compression emerged as an alternative to CNT-supported glassy carbon for implantable devices; however, the pellet electrodes suffer from limitations including being fragile and brittle ${ }^{17}$ which, for example, can lead to unwanted release of nanotubes into the organism and reduced catalytic lifetimes. The $c a .1 \mathrm{~cm}^{3}$ geometric volume of CNT pellet bioelectrodes implanted in rats was also larger than ideal and resulted in diffusional transport limitations. For implantable and particularly wearable applications, porous electrodes which are soft, flexible, biocompatible and even stretchable are highly desirable. ${ }^{15}$ Buckypaper is an emerging paper-like material with attractive qualities for interfacing biological and electrochemical systems for implantable and wearable applications, including enzymatic biofuel cells. ${ }^{40,41}$ Buckypaper has also gained attention for a plethora of applications, for example; for supercapacitor electrodes, ${ }^{42,43}$ electromechanical actuators (artificial muscles), ${ }^{44-46}$ fuel cells ${ }^{47,48}$ and batteries, ${ }^{49-}$ 51 sensors and biosensors, ${ }^{52-54}$ scaffolds for retinal cells transplantation, ${ }^{55}$ separation and fire protection membranes, ${ }^{56-58}$ and for electromagnetic interference

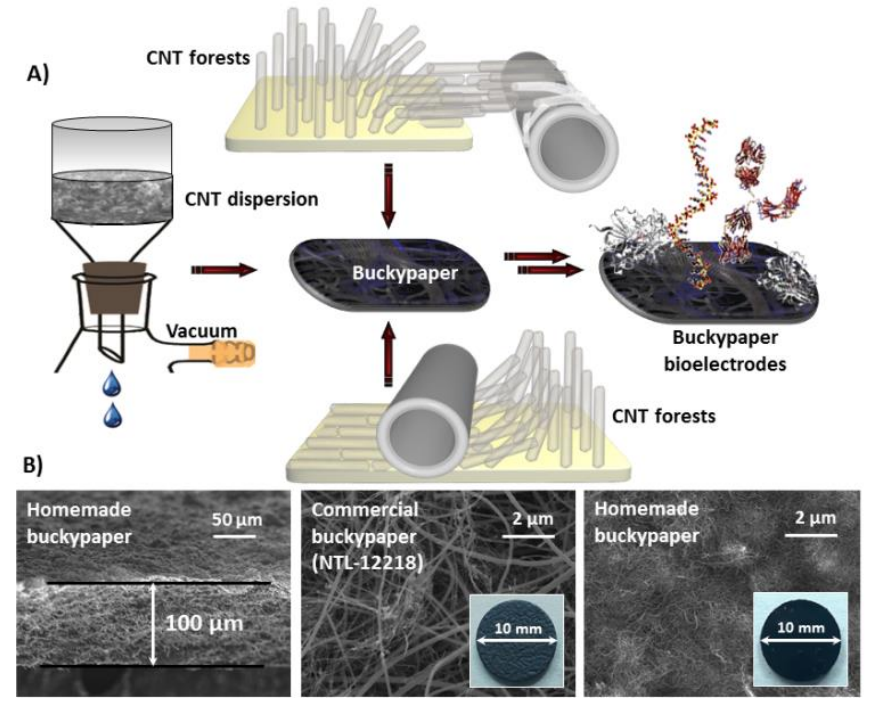

Figure 1: A) Visualized methods for buckypaper production based on filtration and rolling processing, followed by post-functionalisation to obtain buckypaper bioelectrodes. B) SEM images and photographs of homemade buckypaper and commercial buckypaper samples.

shields. ${ }^{59,60}$ The development of buckypaper materials is thus of general interest to a vast research and industrial community with great promise to help address societal challenges in energy, medical and materials science.

Over the last 5-7 years, buckypaper has emerged for construction of bioelectronics devices including biological fuel cell systems, ${ }^{41,61}$ biologic systems ${ }^{62}$ and biosensors. ${ }^{44,63-65}$ This review herein shall give an overview concerning the developments and achievements of buckypaper for construction of enzyme-based bioelectrodes and biofuel cells for implantable and wearable energy harvesting devices.

\section{Buckypapers in bioelectrochemistry}

Buckypapers (BPs) are thin self-supporting macroscopic sheets of entangled carbon nanotubes (CNTs) held together by $\pi-\pi$ stacking and interweaving interactions with a typical thickness of 5-200 $\mu \mathrm{m}$ that can decrease down to $200 \mathrm{~nm} .^{66-67}$ The term "buckypaper" originates from the colloquial name for CNTs of "buckytubes", inspired by the 1996 Noble Prizewinning discovery of "buckyballs" by Smalley, Curl and Kroto. ${ }^{68}$ Smalley's group first reported the possibility to form a selfsupporting sheet of carbon nanotubes, "buckypaper", in $1998 .{ }^{69}$ In this seminal work, single-walled carbon nanotube buckypaper was formed by vacuum filtration of a CNT suspension containing a non-ionic surfactant, Triton X-100. The carbon nanotube sheets were used simply as control samples for characterizing the production and purity of SWCNTs.

Buckypaper is now the well accepted term for disordered and aligned carbon nanotube sheets, including composite materials, formed by vacuum filtration of aqueous and nonaqueous dispersions of single-walled, double-walled and multiwalled carbon nanotubes (SWCNTs, DWCNTs, and MWCNTs, respectively). ${ }^{60,69}$ Buckypaper can also be produced via rolling methods, such as "domino pushing" and CNT drawing and winding. ${ }^{70-71}$ Domino pushing involves rolling a CNT forest with 
constant pressure onto a solid substrate. ${ }^{70}$ The alternative rolling method involves drawing CNTs from a CNT forest and winding the newly-forming CNT sheet on a rotating plastic roll. ${ }^{71}$ Figure 1 visualizes the principle methods for buckypaper production and provides images and photographs of different buckypapers.

Buckypapers are typically formed by filtration of a dispersion of CNTs from aqueous solution prepared by sonication in the presence of a non-ionic surfactant. Surfactants such as Triton X-100, sodium dodecylbenzenesulfonate (SDBS) and sodium dodecyl sulfate (SDS) are used to improve the dispersibility of the CNTs. ${ }^{49,72-75}$ Sonication and centrifugation treatments of the dispersions are subsequently performed to improve their quality and purity. The CNT suspension is subsequently filtered through a micron porous membrane such as a Teflon or polycarbonate filter under positive or negative pressure. ${ }^{76-77}$ The freestanding CNT sheet is finally obtained, after washing, drying and careful peeling from the underlying filter. To remove unwanted additives and impurities from the buckypaper, which is especially important before interfacing enzymes due to potential denaturation, treatments include washing the buckypaper (e.g. with nitric acid, isopropanol and/or methanol) and heat treatment. ${ }^{73,76,78,79}$ Heat treatment is also an effective method to remove any residual solvent.

Buckypaper fabrication is conceptually straightforward but factors such as the suspension homogeneity, CNT length and purity, surface charge and functionality of the CNTs, filter pore size, the presence of additives, and the procedure to dry and remove the CNT paper from the filter, all create challenges with respect to material reproducibility and functionality. Many protocols for buckypaper fabrication have been reported to give functional materials with desirable properties. For example, some studies have focused on tuning the physical and mechanical properties of buckypaper including porosity, permeability, tensile strength, Young's modulus, hardness and electrical conductivity. ${ }^{60,80-84}$

For construction of bioelectrodes, surfactant-free production of buckypaper is highly desirable because residual surfactant adsorbed on the CNTs can hamper electrical conductivity, chemical functionality, and create mechanically unstable regions within the films. Park et al. studied solvent effects on buckypaper and highlighted the importance of removing residual solvent to improve the physical properties of buckypaper materials. ${ }^{74}$ The presence of a surfactant such as Triton X-100 can also lead to cell lysis and tissue inflammation at low concentration, posing biocompatibility concerns. Surfactant-free fabrication methods have also been developed. ${ }^{40,85,86} \mathrm{~A}$ straightforward surfactant-free approach is to use chemically functionalized carbon nanotubes. The classical strategy to functionalize CNTs to improve dispersion quality is to introduce carboxylic acid surface functionalities via strong acid treatment. ${ }^{54,87}$ The introduction of oxygenated functionalities such as carboxylic acid groups to the surface of CNTs increases the hydrophilicity of the CNTs. Physical surface modification of CNTs can also be used such to introduce oxygenated functionalities, for example, via oxygen plasma treatment. ${ }^{88}$ The use of aryldiazonium salt surface chemistry is an attractive method of functionalizing CNTs and buckypapers with a wide range of functional groups via covalent bonds. ${ }^{87,89-}$ 92 Covalent surface chemistry can be used to improve the dispersion of CNTs but could also be adapted to improve the surface chemistry of buckypaper electrodes, for example, for interfacing enzymes or to resist biofouling. ${ }^{93,94} \mathrm{~A}$ crucial factor to consider is that covalent surface modification can disrupt the extended pi-conjugation of CNTs. This could adversely influence the electrical characteristics of the buckypaper; hence careful control over the extent of modification is required. Non-covalent surface modification chemistry, for example, based on pyrene derivatives is a highly effective approach for chemical functionalisation of CNTs and buckypapers. ${ }^{95-98}$

Filtration of CNT dispersions prepared with non-aqueous solvents such as $\mathrm{N}, \mathrm{N}$-dimethylformamide (DMF) is effective for the production of high purity buckypaper without the need for a surfactant. ${ }^{40,54,85,99}$ However, DMF is a hazardous solvent and its high boiling point makes it harder to remove. Appropriate aqueous washing and vacuum or heat treatment steps can be employed to remove non-aqueous solvents such as DMF from the buckypaper. The removal of toxic solvents is of paramount importance to minimize enzyme denaturation but also to minimize material toxicity with respect to in-vivo applications. An advantage of non-aqueous solvents is the possibility to dissolve a wide range of hydrophobic molecules and polymers such as polynorbornenes, redox polymers, heteroaromatics and pyrene-derivatives for preparation of functional buckypapers. ${ }^{40,85,86,100}$ Alternative more eco-friendly solvents such as ethanol and isopropyl alcohol, which are less toxic and have a lower boiling point, have also been successfully employed and warrant further use. ${ }^{101,102}$

Continuous batch manufacture methods are now exploited for fabrication of CNT buckypapers, for example, based on filtration, roll-to-roll and undisclosed methods including CNT crosslinking methods. ${ }^{75,83}$ Buckeye Composites is a wellestablished division of NanoTechLabs Inc. providing commercially available buckypaper samples which have been widely reported for construction of bioelectrodes. ${ }^{41,65,99,103,104}$ Conductive MWCNT buckypaper sheets can also be obtained from NanoLab Inc. ${ }^{105,106}$ and Nanocomp Technologies Inc., ${ }^{107}$ although to the best of our knowledge, these materials have not yet been reported for use as electrodes or bioelectrodes.

An important advantage of buckypapers compared to other 3D-structured carbon electrodes types (e.g. CNT deposits on glassy carbon (GC) electrodes) ${ }^{108}$ is that they benefit from being free-standing: no additional support for current collection or physical stabilisation is required. Buckypaper electrodes also benefit from being lightweight, having high CNT densities (e.g. compared to CNT pellet electrodes), ${ }^{109}$ and being easily processed into different shapes and sizes (which is not possible using classical graphitic electrodes). Buckypapers are highly porous structures comprising mesopores (diameter 2-50 $\mathrm{nm}$ ) and small macropores (diameter $>50 \mathrm{~nm}$ ), and a large free volume of up to $c a .80-90 \%,{ }^{73}$ depending on factors such as the casting solvent used. To date, the fine tuning of the 
porous structure of buckypaper electrodes for biofuel cell applications has not been reported. Nevertheless, existing studies on 3D-structured porous carbons, for use in biofuel cells, have highlighted the importance of macropores for high rates of mass transport for bioelectrocatalysis. ${ }^{34}$ Mesopores on the other hand are necessary to provide high surface areas per volume and, potentially, enhance electron transfer due to intimate contact of the enzyme to the surface. ${ }^{34}$ We recently reported improved bioelectrocatalytic currents for buckypaper which had a larger surface area, a larger mesoporous volume, and smaller mesopores. ${ }^{99}$ It is important to note that other factors such as the nanotube size and carbon defect structure also play an important role for bioelectrocatalysis. Additionally, mesopores with a size similar to that of the enzyme may stabilise enzymes via confinement. ${ }^{39}$ Concerning mechanical properties, existing reports have demonstrated the possibility to improve the strength and hardness of buckypaper materials via alignment of the CNTs ${ }^{60}$ or by using long carbon nanotubes up to $1500 \mu \mathrm{m}$ in length. ${ }^{110}$ Alternatively, incorporation of a "soft" polymeric component has been used to great effect for enhancing the mechanical flexibility of buckypaper. ${ }^{85}$ There exists even the possibility to obtain stretchable buckypapers via incorporation of elastomers such as polyurethane. ${ }^{111}$

The benefits of using CNT-based electrodes for construction of enzymatic electrodes are well known. ${ }^{32}$ Most high performance bioelectrodes to date are based on CNTs owing to their high surface areas, chemical stability, ability to undergo efficient electron transfer with enzymes, and excellent conductivity. ${ }^{11,32}$ CNTs can also be readily modified with chemical functionalities, permitting effective immobilization, stabilization and orientation of enzymes for effective electron transfer between the electrode and enzyme. ${ }^{32,112-114}$ There are clearly many factors which should be carefully considered when developing buckypaper materials for enzymatic bioelectrode interfaces.

\section{Buckypapers for bioenergy conversion}

\section{Enzymatic bioanodes}

Enzymatic bioanodes are electrodes with at least one immobilized oxidoreductase enzyme that are capable of oxidizing a fuel or several fuels (e.g. sugars and alcohols) to release electrons. Figure 2 summarizes the different immobilization and enzyme wiring techniques that are used for the construction of enzymatic buckypaper anodes. The figures of merit for buckypaper bioanodes are summarized in Table 1.

The first example of a buckypaper bioanode was reported in 2011 and was inspired by a step in one of nature's energyharvesting cycles, the citric acid cycle. ${ }^{115}$ The SWCNT bioanode was prepared via filtration and modified with polymethylene green. NAD-dependent malate dehydrogenase (from porcine) (NADMDH) was used in solution for oxidation of L-malate with the enzyme's cofactor, $\mathrm{NAD}^{+}$, also in solution. A small maximum catalytic current density of $22 \mu \mathrm{Acm}^{-2}$ at $0.1 \mathrm{~V}$ vs.
$\mathrm{Ag} / \mathrm{AgCl}$ was demonstrated. Nevertheless, this work effectively established an effective bioelectrode system applicable to a large number of NAD-dependent enzymes for oxidation of a wide range of substrates. In subsequent studies, Villarrubia et al. switched to commercial MWCNT buckypaper and enzyme immobilization for bioelectrode construction. ${ }^{97,103,116}$ In some cases, an additional catalytic layer comprising MWCNTs, chitosan, and enzyme was immobilized on the polymethylene green buckypapers. ${ }^{97,103}$ The authors investigated the oxidation of lactate, alcohol and glucose via their respective NAD-dependent dehydrogenases from Pseudomonas sp., Lactobacillus leichmanii, and Bakers yeast, respectively. The best performing anode was the glucose-oxidizing bioanode which delivered an impressive maximum catalytic current of $3.38 \mathrm{mAcm}^{-2}$ and good stability with $\mathrm{ca}$. $65 \%$ of the initial performance remaining after 30 days of storage. ${ }^{103}$ In contrast, the lactate- and ethanol-oxidizing bioanodes delivered smaller catalytic currents of 53.4 and $226.6 \mu \mathrm{Acm}^{-2}$. All three bioanodes nevertheless showed improved catalytic performance compared to the L-malate bioanode. ${ }^{115}$ At this point, it is important to note that glucose is present in high concentrations in the blood (typically 4.9-6.9 $\mathrm{mmol} \mathrm{L}^{-1}$ ) and is arguably the most attractive fuel for implantable biofuel cells. ${ }^{109,117}$ In contrast, lactate is highly abundant in human sweat, much more so than glucose, and is a promising fuel for wearable biofuel cells (lactate $\approx 10$ to $100 \mathrm{mmol} \mathrm{L}^{-1}$ and glucose $\leq 1 \mathrm{mmol} \mathrm{L}-1) \cdot{ }^{118,119}$ Alcohol is less attractive for both implantable and wearable applications owing to its low endogenous production $\left(<50 \mu \mathrm{mol} \mathrm{L}{ }^{-1}\right) .{ }^{120}$ Implantable and wearable alcohol-consuming biofuel cells would thus rely on regular alcohol consumption or exposure to achieve $\mathrm{mmol} \mathrm{L}^{-1}$ concentrations in-vivo. ${ }^{121}$ Alcohol-based biofuel cells are hence more appropriate for powering portable devices, for example, from alcoholic drinks or agricultural feedstock.

For the development of implantable power sources, it is practical to construct bioanodes that do not require enzyme cofactor to be added in solution. With this in mind, Villarrubia and coworkers developed MWCNT buckypaper anodes with NAD-dependent enzymes and their cofactor immobilized on the surface. ${ }^{97}$ The $\mathrm{NAD}^{+} / \mathrm{NADH}$ cofactor was attached to the electrode via a pyrene butanoic acid succinimidyl ester (PBSE) crosslinker. The bioanode with immobilized cofactor delivered a high catalytic current density of $c a .3 .1 \mathrm{mAcm}^{-2}$ at $0.05 \mathrm{~V}$ vs. $\mathrm{Ag} / \mathrm{AgCl}$ with $100 \mathrm{mmol} \mathrm{L}^{-1}$ glucose and thus similar catalytic output to the previously reported bioanode with the cofactor in solution $\left(3.38 \mathrm{mAcm}^{-2}\right)$. Unfortunately, the bioanode with immobilized cofactor suffered from a significant stability loss over 2 days, attributed to desorption of the cofactor from the electrode. Future work should address the stability issue of immobilized cofactor. In addition, Villarrubia and coworkers compared two types of MWCNT buckypaper (from Buckeye Composites) for bioelectrocatalysis and reported improved electron transfer and mass transport for the buckypaper which had variable pore sizes and CNT diameters. ${ }^{97}$ In later work, the bioanode with immobilized cofactor was used for the construction of a paper-based biofuel cell flow device. ${ }^{97,116}$

Reid et al. and Lalaoui et al. also developed buckypaper 
bioanodes with immobilized NAD-dependent dehydrogenases. ${ }^{122,123}$ In the work by Reid et al., commercial MWCNT buckypaper (27 gsm, 87\% porosity, $2.07 \Omega \mathrm{sq}^{-1}$ ) was modified with polymethylene green, NAD-dependent lactate dehydrogenase from Escherichia coli and $\mathrm{NAD}^{+}$cofactor. In addition, the electrode was modified with a polyethyleneimene hydrogel and an ethylene glycol diglycidyl ether crosslinker to entrap and stabilize the cofactor and enzyme on the surface whilst allowing efficient permeation of the electrolyte and fuel. ${ }^{122}$ Towards the development of wearable biofuel cells, various electrode materials were explored including Toray carbon paper and evaporated gold films. Buckypaper was eventually chosen by the authors owing to its superior flexibility, surface area, mechanical strength and conductivity. A maximum catalytic current density of ca. 5 $\mu \mathrm{Acm}^{-2}$ at $0.25 \mathrm{~V}$ vs. $\mathrm{Ag} / \mathrm{AgCl}$ for lactate oxidation was reported in synthetic tear solution. Low catalytic currents were observed in the presence of ascorbate (a component of tear fluid) due to competition between ascorbate and NADH for use of polymethylene green as the electrocatalyst/mediator. Lalaoui et al. reported homemade MWCNT buckypaper anodes with immobilized NAD-dependent glucose dehydrogenase from Pseudomonas sp. Either a pyrene-modified Ru complex or diaphorase from Clostridium kluyveri was immobilized on the electrode to facilitate catalytic glucose oxidation. ${ }^{123}$ The diaphorase bioanode had the advantage of low overpotentials for NADH oxidation whereas the Ru complex bioanode exhibited higher catalytic currents.

Katz and coworkers pioneered the development of bioanodes for implantable biofuel cells using MWCNT buckypaper (from Buckeye Composites).41,124-126 Glucoseoxidizing bioanodes modified with PQQ-dependent GDH (PQQGDH) via PBSE crosslinker have been implanted in snails, ${ }^{41}$ clams, ${ }^{124}$ rats $^{125}$ and lobsters. ${ }^{126}$ The first buckypaper bioanodes, developed for implantation in clams, used indium tin oxide (ITO, $20 \Omega \mathrm{sq}^{-1}$ ) as a rigid mechanical support. ${ }^{41124}$ The ITO-buckypaper anodes delivered a maximum catalytic current of ca. $50 \mu \mathrm{A}$ (ca. $200 \mu \mathrm{Acm}^{-2}$ ) at $0.4 \mathrm{~V}$ vs. $\mathrm{Ag} / \mathrm{AgCl}$. Katz and coworkers highlighted practical advantages of buckypaper for implantation compared to traditional bulk electrodes, such as their ideal microscale thickness and tuneable dimensions. In one example, small anodes were cut for insertion into the exoskeleton of lobsters via $0.2 \times 1 \mathrm{~cm}$ incisions. ${ }^{126}$ In another example, large anodes were cut to size $\left(6 \mathrm{~cm}^{2}\right)$ to provide enough current to power interfacial electronics and a pacemaker. ${ }^{127}$

Table 1: Figures of merit for enzymatic buckypaper bioanodes

\begin{tabular}{|c|c|c|c|c|c|c|c|c|}
\hline Year & Buckypaper & $\begin{array}{c}\text { Mediator/Elec } \\
\text { trocatalyst }\end{array}$ & $\begin{array}{l}\text { Electron } \\
\text { Transfer }\end{array}$ & Enzyme & Substrate & Current Density & Conditions & Ref \\
\hline 2011 & $\begin{array}{l}\text { Homemade } \\
\text { SWCNT }\end{array}$ & $\begin{array}{l}\text { Polymethylene } \\
\text { green }\end{array}$ & $\begin{array}{l}\text { Pseudo- } \\
\text { DET }\end{array}$ & NADMDH & Malate & $22 \mu \mathrm{Acm}^{-2}$ (0.1 V vs AgAgCl) & $\begin{array}{c}\text { Phosphate buffer } \mathrm{pH} 7 \text {, } \\
\qquad A D^{+} \text {in solution }\end{array}$ & 115 \\
\hline 2012 & $\begin{array}{c}\text { Commercial } \\
\text { MWCNT }\end{array}$ & - & DET & PQQGDH & Glucose & $200 \mu \mathrm{Acm}^{-2}(0.4 \mathrm{~V} \text { vs AgAgCl})^{[i]}$ & $\begin{array}{c}\text { Synthetic hemolymph } \\
\text { pH 7.4 }\end{array}$ & 41 \\
\hline 2012 & $\begin{array}{c}\text { Commercial } \\
\text { MWCNT }\end{array}$ & - & DET & PQQGDH & Glucose & $200 \mu \mathrm{Acm}^{-2}(0.4 \mathrm{~V} \text { vs AgAgCl})^{[i]}$ & MOPS buffer $\mathrm{pH} 7$ & 124 \\
\hline \multirow{2}{*}{2013} & \multirow{2}{*}{$\begin{array}{c}\text { Homemade } \\
\text { MWCNT } \\
\text { /SWCNT }\end{array}$} & \multirow{2}{*}{-} & \multirow{2}{*}{ DET } & \multirow{2}{*}{ PQQGDH } & Glucose & $35 \mu \mathrm{Acm}^{-2}(0.35 \mathrm{~V}$ vs $\mathrm{AgAgCl})$ & $\begin{array}{l}\text { MOPS buffer } \mathrm{pH} 7, \mathrm{PQQ} \\
\text { in solution }\end{array}$ & \multirow{2}{*}{10} \\
\hline & & & & & $\begin{array}{c}\text { Mono/disa } \\
\text { ccharides }\end{array}$ & $3 \mu \mathrm{Acm}^{-2}(0.25 \mathrm{~V}$ vs AgAgCl) & MOPS buffer pH 7 & \\
\hline \multirow{3}{*}{2013} & \multirow{3}{*}{$\begin{array}{c}\text { Commercial } \\
\text { MWCNT }\end{array}$} & \multirow{3}{*}{$\begin{array}{l}\text { Polymethylene } \\
\text { green }\end{array}$} & \multirow{3}{*}{$\begin{array}{l}\text { Pseudo- } \\
\text { DET }{ }^{[i i i]}\end{array}$} & NADGDH & Glucose & $3.38 \mathrm{mAcm}^{-2}$ & \multirow{3}{*}{$\begin{array}{l}\text { Phosphate buffer } \mathrm{pH} \\
7.5, \mathrm{NAD}^{+} \text {in solution }\end{array}$} & \multirow{3}{*}{103} \\
\hline & & & & NADLDH & Lactate & $53.4 \mu \mathrm{Acm}^{-2}$ & & \\
\hline & & & & NADADH & Ethanol & $226.6 \mu \mathrm{Acm}^{-2}$ & & \\
\hline 2014 & $\begin{array}{c}\text { Commercial } \\
\text { MWCNT }\end{array}$ & $\begin{array}{l}\text { Polymethylene } \\
\text { green }\end{array}$ & $\begin{array}{l}\text { Pseudo- } \\
\text { DET'[iii] }\end{array}$ & NADGDH & Glucose & $3.1 \mathrm{mAcm}^{-2}(0.05 \mathrm{~V}$ vs $\mathrm{AgAgCl})$ & $\begin{array}{l}\text { Phosphate buffer } \mathrm{pH} \\
\text { 7.5, } \mathrm{NAD}^{+} \text {immobilized }\end{array}$ & 97 \\
\hline 2014 & $\begin{array}{c}\text { Commercial } \\
\text { MWCNT }\end{array}$ & $\begin{array}{l}\text { Pyrroloquinoli } \\
\text { ne quinone }\end{array}$ & DET & PQQGDH & Glucose & $750 \mu \mathrm{Acm}^{-2}(0.3 \mathrm{~V}$ vs $\mathrm{AgAgCl})$ & $\begin{array}{c}\text { Citrate-phosphate buffer } \\
\mathrm{pH} 7\end{array}$ & 135 \\
\hline 2015 & $\begin{array}{c}\text { Commercial } \\
\text { MWCNT }\end{array}$ & $\begin{array}{l}\text { Polymethylene } \\
\text { green }\end{array}$ & $\begin{array}{l}\text { Pseudo- } \\
\text { DET[iii] }\end{array}$ & NADLDH & $\begin{array}{l}\text { Lactate, } \\
\text { Ascorbate }\end{array}$ & $5 \mu \mathrm{Acm}^{-2}(0.25 \mathrm{~V}$ vs AgAgCl) & $\begin{array}{c}\text { Synthetic tears } \mathrm{pH} 7.4 \\
\mathrm{NAD}^{+} \text {in solution }\end{array}$ & 122 \\
\hline 2015 & $\begin{array}{c}\text { Commercial } \\
\text { MWCNT }\end{array}$ & - & DET & $\begin{array}{l}\text { FADFDH, } \\
\text { PQQGDH }\end{array}$ & $\begin{array}{c}\text { Fructose, } \\
\text { Glucose }\end{array}$ & $75 \mu \mathrm{Acm}^{-2}(0.4 \mathrm{~V} \mathrm{vs} \mathrm{AgAgCl})^{[i]]}$ & Phosphate buffer pH 7.4 & 128 \\
\hline \multirow{2}{*}{2016} & \multirow{2}{*}{$\begin{array}{l}\text { Commercial } \\
\text { MWCNT }\end{array}$} & \multirow{2}{*}{$\begin{array}{l}\text { Pyrroloquinoli } \\
\text { ne quinone }\end{array}$} & \multirow{2}{*}{ DET } & \multirow{2}{*}{ PQQGDH } & \multirow{2}{*}{ Glucose } & $1 \mathrm{mAcm}^{-2}(0.25 \mathrm{~V}$ vs AgAgCl$)$ & Human urine, glucose & \multirow{2}{*}{134} \\
\hline & & & & & & $250 \mu \mathrm{Acm}^{-2}(0.4 \mathrm{~V}$ vs AgAgCl$)$ & Human saliva, glucose & \\
\hline 2017 & $\begin{array}{c}\text { Homemade } \\
\text { MWCNT }\end{array}$ & $\begin{array}{l}\text { Phenanthrolin } \\
\text { e quinone }\end{array}$ & MET & FADGDH & Glucose & $5.4 \mathrm{mAcm}^{-2}(0.2 \mathrm{~V}$ vs SCE$)$ & Mcllvaine buffer $\mathrm{pH} 7$ & 40 \\
\hline 2017 & $\begin{array}{c}\text { Homemade } \\
\text { MWCNT }\end{array}$ & $\begin{array}{c}\text { Osmium redox } \\
\text { polymer }\end{array}$ & MET & FADGDH & Glucose & $1.0 \mathrm{mAcm}^{-2}(0.3 \mathrm{~V}$ vs $\mathrm{AgAgCl})$ & Acetate buffer pH 5.5 & 138 \\
\hline 2017 & $\begin{array}{l}\text { Commercial } \\
\text { MWCNT }\end{array}$ & Meldola Blue & MET & LOx & Lactate & $2.1 \mathrm{mAcm}^{-2}$ (0.05 V vs AgAgCl) & Phosphate buffer $\mathrm{pH} 6$ & 139 \\
\hline
\end{tabular}

Estimated from reported geometric electrode areas of [i] $0.25 \mathrm{~cm}^{2}$ and [ii] $2 \mathrm{~cm}^{2}$. [iii] Pseudo-DET where electron transfer occurs between the electrode and enzyme via unbound NAD coenzyme, facilitated by an electrocatalyst. 


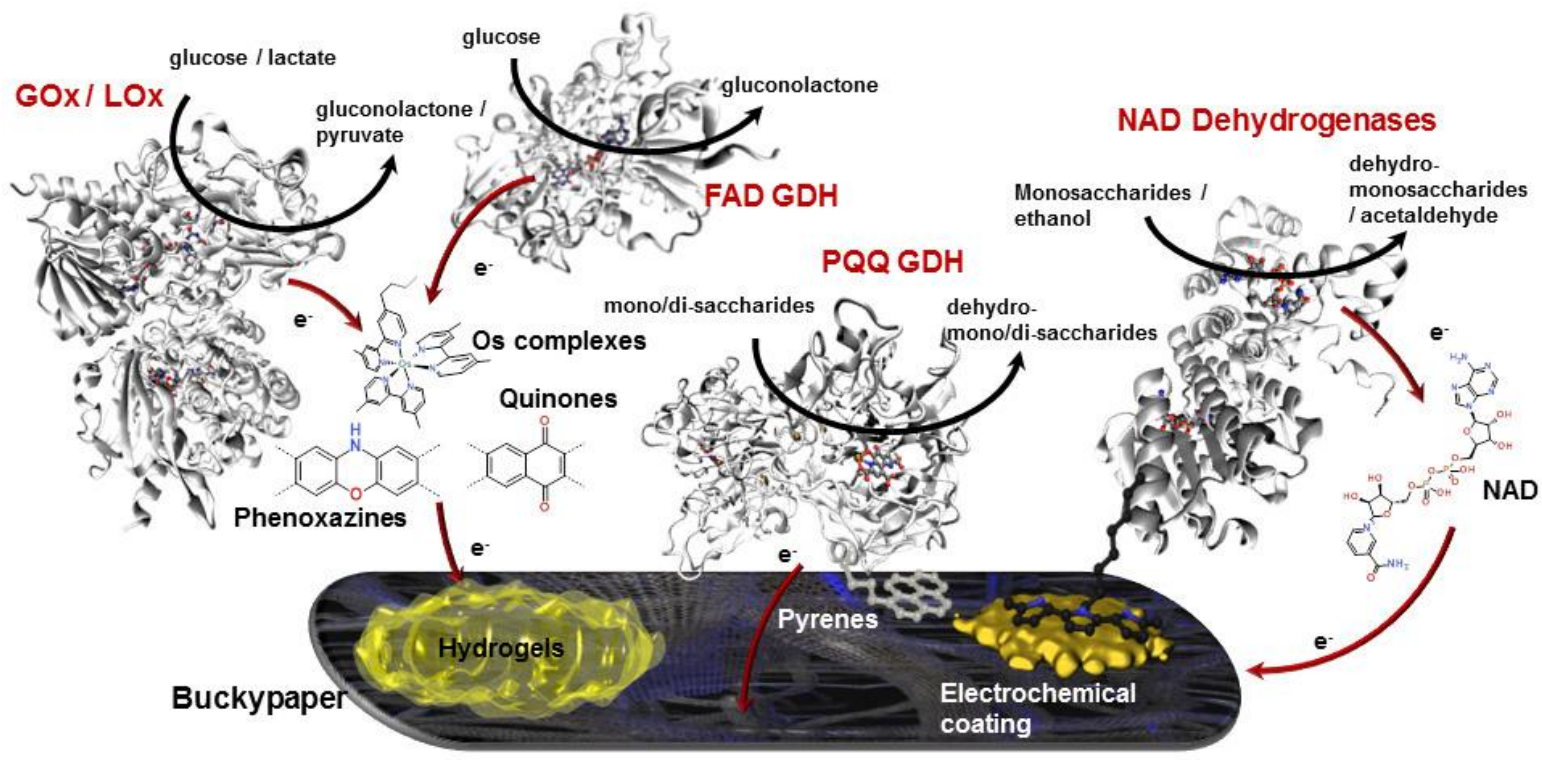

Figure 2: Immobilization and electrical wiring strategies for different organic substrate oxidizing enzymes.

Another key development from the Katz group was a dualenzyme dual-substrate bioelectrode with immobilized PQQGDH and FAD-dependent fructose dehydrogenase (FADFDH) from Gluconobacter industrius. ${ }^{128}$ A maximum catalytic current of $150 \mu \mathrm{A}$ (ca. $75 \mu \mathrm{Acm}^{-2}$ ) at $0.4 \mathrm{~V} \mathrm{vs.} \mathrm{Ag} / \mathrm{AgCl}$ was achieved. The advantage of oxidizing two fuels (glucose and fructose) rather than one was only evident at high potentials of $>0.3 \mathrm{~V}$.

PQQGDH is an attractive enzyme for bioanode construction as it can be produced recombinantly, is characterized by high catalytic activity for several sugars (such as glucose, galactose, lactose and maltose), and can achieve DET and MET between its catalytic centre and electrodes. ${ }^{129-131}$ Also, like the other dehydrogenases, PQQGDH benefits from being insensitive to oxygen which prevents in-situ production of $\mathrm{H}_{2} \mathrm{O}_{2}$ which can deactivate the biocathode of biofuel cells. ${ }^{132,133}$ Furthermore, unlike NAD-dependent enzymes, the addition of cofactor in solution (or on the surface) is not required! However, PQQGDH can suffer from inherently limited stability, for example, compared to GOx, unless the enzyme is rationally modified by protein engineering. ${ }^{131}$

Lisdat and coworkers explored the use of buckypaper (from Buckeye composites) modified with poly(3aminobenzoic acid-co-2-methoxyaniline-5-sulfonic acid) (PABMSA) and reconstituted PQQGDH from Acinetobacter calcoaceticus. ${ }^{134,135}$ To increase stability, the enzyme was covalently tethered by 1-ethyl-3-(3-dimethylaminopropyl) carbodiimide (EDC)/N-hydroxysuccinimide (NHS) coupling chemistry via the carboxylic acid groups of the sulfonated polymer. In the first report, a maximum current density of 0.75 $\mathrm{mAcm}^{-2}$ for glucose oxidation was observed using the optimized polymer and buffer conditions. ${ }^{135}$ Using the same type of bioanode, Lisdat and coworkers shed light on the effect of interfering substances on glucose oxidation in human saliva and urine. ${ }^{134}$ For example, these investigations show that ascorbic acid and uric acid are both electrochemically oxidized at similar potentials to glucose and thus have an impact on the biocatalytic process.

Atanassov and coworkers also developed bioanodes with SWCNT and MWCNT buckypapers (from Buckeye Composites) modified with PQQGDH via PBSE crosslinker. In addition to demonstrating the oxidation of glucose, the bioanodes were tested for oxidation of alternative sugars including maltose, lactose and galactose. ${ }^{104}$ Several aspects of anode performance were considered including catalysis, nanotube architecture, PQQ redox behaviour and enzyme stability. A

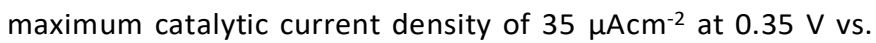
$\mathrm{Ag} / \mathrm{AgCl}$ was observed at SWCNT buckypaper with glucose as the fuel and PQQ present in solution. The use of PQQ in solution at the bioanode was not essential but increased the redox activity by a factor of 3 .

The construction of a buckypaper bioanode with an FADdependent enzyme for glucose oxidation was only recently reported, which is surprising given the widespread use of such enzymes as oxygen-insensitive alternatives to GOx for biosensor and biofuel cell applications. ${ }^{136,137}$ We developed a homemade MWCNT buckypaper anode modified with 1,10phenanthroline-5,6-dione (PLQ) and FAD-dependent glucose dehydrogenase (FADGDH) from Aspergillus sp. Well-defined steady state voltammograms and a high catalytic current density of $5.4 \mathrm{mAcm}^{-2}$ at $0.2 \mathrm{~V}$ vs. SCE for glucose oxidation was obtained with $170 \mathrm{mmol} \mathrm{L}^{-1}$ glucose. ${ }^{40}$ The onset potential of $-0.23 \mathrm{~V}$ vs. SCE for mediated glucose oxidation was attractively low. Hou and Liu have since developed a FADGDHbased buckypaper hydrogel anode for glucose oxidation using the same fungal species (Aspergillus sp.). ${ }^{138}$ The homemade MWCNT buckypaper was modified with polyethylene glycol diglycidyl ether (PEGDGE) and an Os complex redox polymer. Maximum catalytic current densities up to $1.0 \mathrm{mAcm}^{-2}$ at $0.3 \mathrm{~V}$ vs. $\mathrm{Ag} / \mathrm{AgCl}$ were obtained for glucose oxidation with $30 \mathrm{mmol}$ $\mathrm{L}^{-1}$ glucose. Compared to the FADGDH-based PLQ anode developed by Gross et al, the catalytic current output is lower. For example, the PLQ bioanode produced $2 \mathrm{mAcm}^{-2}$ at $0.2 \mathrm{~V}$ vs. 
SCE with only $20 \mathrm{mmol} \mathrm{L}^{-1}$. However, the FADGDH-based hydrogel anode with the Os complex mediator exhibited far better stability over 3 days compared to the PLQ bioanode.

Dong and coworkers reported a wearable bioanode for oxidation of lactate in sweat. ${ }^{139}$ Commercial buckypaper (Buckeye Composites) was modified with meldola blue mediator then lactate oxidase (LOx) from Pediococcus sp. and a chitosan encapsulation layer. A high maximum catalytic current density of $2.12 \mathrm{mAcm}^{-2}$ at $0.05 \mathrm{~V}$ vs. $\mathrm{Ag} / \mathrm{AgCl}$ with an onset potential of $-0.05 \mathrm{~V}$ was achieved with $30 \mathrm{mmol} \mathrm{L}^{-1}$ lactate. The use of LOx rather than lactate dehydrogenase is attractive as the cofactor is already tightly bound in the enzyme. However, the enzyme consumes valuable oxygen and produces toxic $\mathrm{H}_{2} \mathrm{O}_{2}$ as a by-product. To minimize the negative effect of $\mathrm{H}_{2} \mathrm{O}_{2}$, future buckypaper bioanodes could incorporate a second catalytic species at the bioanode, such as catalase, to decompose the $\mathrm{H}_{2} \mathrm{O}_{2} .{ }^{140,141}$

\section{Enzymatic biocathodes}

The most widely investigated oxidant employed in enzymatic biocathodes is oxygen. Since dissolved oxygen is present in biological fluids including extracellular fluid, blood, sweat, urine and tears, it is a practical substrate for wearable and implantable bioelectrodes. However, it must be emphasized that oxygen concentrations in-vivo are much lower than in airsaturated and oxygen-saturated buffer solutions which are typically employed for biocathode and biofuel cell evaluation. For example, free oxygen concentration is almost 5 -fold lower in blood and ten-fold lower in saliva compared to air-saturated solutions (ca. $0.2 \mathrm{mmol} \mathrm{L}^{-1}$ ). ${ }^{142}$ The large majority of oxygenreducing biocathodes employ the MCO enzymes; laccase from Trametes versicolor (TVLC) and bilirubin oxidase from Myrothecium verrucaria $(\mathrm{MvBOx}) .^{24,143}$ These enzymatic electrodes catalyze the four-electron reduction of oxygen to water at near neutral $\mathrm{pH}$ with a high formal potential close to that of the $\mathrm{O}_{2} / \mathrm{H}_{2} \mathrm{O}$ couple $(0.816 \mathrm{~V}$ vs. RHE at $\mathrm{pH} 0) .{ }^{40} \mathrm{In}$ addition, this class of enzymes can undergo direct and/or mediated electron transfer with carbon nanotubes. ${ }^{86,144-146}$ Figure 3 summarizes different immobilization and enzyme wiring principles used for the construction of laccase- and BOxbased buckypaper biocathodes. Table 2 summarizes the figures of merit for buckypaper biocathodes.

The first buckypaper biocathodes were reported in 2011 by Hussein and coworkers. ${ }^{67,147,148}$ The authors developed various methods for the fabrication of MWCNT and acid-treated MWCNT buckypapers via aqueous and non-aqueous suspensions. ${ }^{67}$ Cathodes were prepared by adsorption of biocatalyst inks containing enzyme ( $T V L C$ or $M v B O x$ ), Nafion binder, and ABTS mediator. ${ }^{67,147} \mathrm{~A}$ catalytic current density of $0.23 \mathrm{mAcm}^{-2}$ at $0.65 \mathrm{~V}$ vs. RHE was achieved using the MvBOx biocathode prepared with acid-treated MWCNT buckypaper and ABTS mediator. ${ }^{67}$ Similar catalytic currents were also demonstrated without the ABTS mediator. A more significant result was the 1.5-fold increase observed for MWCNT buckypaper prepared from acid-treated CNTs rather than asreceived non-functionalized CNTs. Improved catalytic currents up to $0.422 \mathrm{mAcm}^{-2}$ at $0.744 \mathrm{~V}$ vs. NHE were observed in a

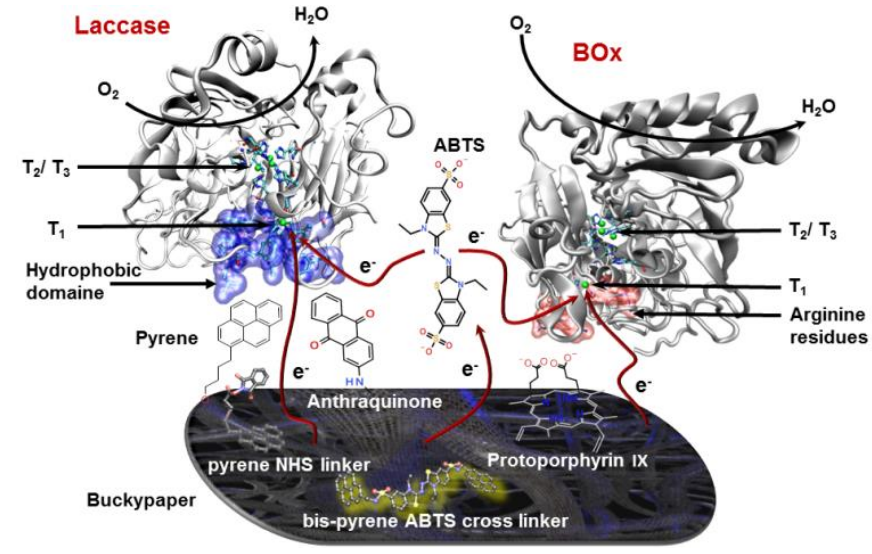

Figure 3: Illustration of different immobilization and wiring principles for direct or mediated electron transfer for multicopper enzymes (laccase and $\mathrm{BO}$ ).

second study using mediatorless MWCNT buckypaper prepared from as-received CNTs modified with laccase. ${ }^{147}$ The best performing biocathode from the three reports was the MWCNT buckypaper modified with biocatalyst ink containing ABTS, additional acid-treated CNTs and MvBOx. ${ }^{148}$ This biocathode delivered $0.7 \mathrm{mAcm}^{-2}$. Compared to an equivalent bioelectrode prepared with carbon black instead of carbon nanotubes, 2.5 -fold more catalytic current was observed. ${ }^{148}$ The enhanced performance was attributed to higher electrical conductivity and a 3-fold higher surface area. In later work, Hussein and coworkers tested homemade MWCNT buckypaper modified with TVLc in a bioreactor compartment with enzyme in solution. ${ }^{149}$ This is an original setup but, unfortunately, a current density of no greater than $0.25 \mathrm{mAcm}$ 2 at $0.7 \mathrm{~V}$ vs. NHE was observed. The poor catalytic performance was likely due to the low enzyme concentration used.

Atanassov and coworkers developed mechanically-robust air-breathing biocathodes from MWCNT buckypaper (from Buckeye Composites) modified with $\mathrm{MvBOx}$ and fused by compression with perforated Toray paper (a commercial catalyst backing layer) and a teflonized carbon black gas diffusion layer. ${ }^{150}$ The incorporation of a gas diffusion layer is highly attractive to improve the mass transport of oxygen to the electrode, thereby addressing a limitation of biofuel cells devices (slow oxygen diffusion relative to fast enzyme kinetics at oxygen biocathodes). However, air-breathing setups are not suitable for implantable applications where only dissolved oxygen is available. Air-breathing cathodes are however potentially suitable for wearable applications if the cathode can be designed such that it is exposed to atmospheric oxygen. Another important innovation by Atanassov and coworkers was the integration of the biocathode in a passive pumping paper-based flow device. ${ }^{150}$ Such a flow device provides a continuous flow of substrate and improved (convective) mass transport of oxygen. A maximum limiting current of 0.48 $\mathrm{mAcm}^{-2}$ at $0 \mathrm{~V}$ vs. $\mathrm{Ag} / \mathrm{AgCl}$ was observed for the flow-based airbreathing buckypaper biocathode, a 2-fold improvement compared to the equivalent biocathode without flow. Villarrubia et al. later exploited the same biocathode design together with a more elegant quasi- 
Table 2: Figures of merit for enzymatic buckypaper biocathodes

\begin{tabular}{|c|c|c|c|c|c|c|c|c|}
\hline Year & Buckypaper & $\begin{array}{c}\text { Mediator/ } \\
\text { DET promoter }\end{array}$ & $\begin{array}{l}\text { Electron } \\
\text { Transfer }\end{array}$ & Enzyme & Substrate & Current Density & Conditions & Ref \\
\hline \multirow{2}{*}{2011} & \multirow{2}{*}{$\begin{array}{l}\text { Homemade } \\
\text { MWCNT }\end{array}$} & - & DET & \multirow{2}{*}{ MvBOx } & \multirow{2}{*}{$\mathrm{O}_{2}$} & $0.24 \mathrm{mAcm}^{-2}$ (0.65 V vs RHE) & \multirow{2}{*}{$\begin{array}{l}\text { Phosphate buffer } \mathrm{pH} \\
7.4 \text {, air-saturated }\end{array}$} & \multirow{2}{*}{67} \\
\hline & & ABTS & MET & & & $0.23 \mathrm{mAcm}^{-2}$ ( $0.65 \mathrm{~V}$ vs RHE $)$ & & \\
\hline \multirow{2}{*}{2011} & \multirow{2}{*}{$\begin{array}{l}\text { Homemade } \\
\text { MWCNT }\end{array}$} & - & DET & \multirow{2}{*}{$T V L c$} & \multirow{2}{*}{$\mathrm{O}_{2}$} & $0.42 \mathrm{mAcm}^{-2}$ ( $0.74 \mathrm{~V}$ vs RHE) & \multirow{2}{*}{$\begin{array}{c}\text { Citrate buffer } \mathrm{pH} 5, \mathrm{O}_{2}- \\
\text { saturated }\end{array}$} & \multirow{2}{*}{147} \\
\hline & & ABTS & MET & & & $0.38 \mathrm{mAcm}^{-2}(0.74 \mathrm{~V}$ vs RHE$)$ & & \\
\hline 2011 & $\begin{array}{c}\text { Commercial } \\
\text { MWCNT }\end{array}$ & ABTS & MET & MvBOx & $\mathrm{O}_{2}$ & $0.70 \mathrm{~mA} \mathrm{~cm}^{-2}$ (0.6 V vs RHE) & $\begin{array}{c}\text { Phosphate buffer } \mathrm{pH} \\
7.4, \mathrm{O}_{2} \text {-saturated }\end{array}$ & 148 \\
\hline 2011 & $\begin{array}{l}\text { Commercial } \\
\text { MWCNT }\end{array}$ & - & DET & TVLC & $\mathrm{O}_{2}$ & $0.13 \mathrm{mAcm}^{-2}(0.1 \vee$ vs $\mathrm{AgAgCl})$ & $\begin{array}{c}\text { Phosphate buffer } \mathrm{pH} \\
5.8, \mathrm{O}_{2} \text {-saturated }\end{array}$ & 62 \\
\hline 2012 & $\begin{array}{l}\text { Commercial } \\
\text { MWCNT }\end{array}$ & - & DET & $T V L c$ & $\mathrm{O}_{2}$ & $0.15 \mathrm{mAcm}^{-2}(0.4 \mathrm{~V} \text { vs AgAgCl})^{[i]}$ & $\begin{array}{l}\text { Synthetic hemolymph } \\
\text { pH } 7.4\end{array}$ & 41 \\
\hline 2012 & $\begin{array}{c}\text { Commercial } \\
\text { MWCNT }\end{array}$ & - & DET & $T v L C$ & $\mathrm{O}_{2}$ & $0.22 \mathrm{mAcm}^{-2}(0.4 \mathrm{~V} \text { vs } \mathrm{AgAgCl})^{[i]}$ & Phosphate buffer $\mathrm{pH} 7.0$ & 124 \\
\hline 2012 & $\begin{array}{l}\text { Commercial } \\
\text { MWCNT }\end{array}$ & - & DET & MvBOx & $\mathrm{O}_{2}$ & $0.48 \mathrm{~mA} \mathrm{~cm}^{-2}$ (0 V vs $\left.\mathrm{AgAgCl}\right)$ & Phosphate buffer $\mathrm{pH} 7.0$ & 150 \\
\hline 2013 & $\begin{array}{l}\text { Homemade } \\
\text { MWCNT }\end{array}$ & - & DET & $T v L c$ & $\mathrm{O}_{2}$ & $1.1 \mathrm{mAcm}^{-2}$ (0.4 V vs AgAgCl) & Phosphate buffer pH 5.8 & 156 \\
\hline \multirow{3}{*}{2013} & \multirow{3}{*}{$\begin{array}{l}\text { Homemade } \\
\text { MWCNT }\end{array}$} & \multirow{3}{*}{-} & \multirow{3}{*}{ DET } & $T h \mathrm{LC}$ & \multirow{3}{*}{$\mathrm{O}_{2}$} & $0.22 \mathrm{mAcm}^{-2}(0.75 \mathrm{~V}$ vs NHE) & $\begin{array}{c}\text { Citrate-phosphate buffer } \\
\mathrm{pH} \mathrm{4.5,} \mathrm{air-saturated}\end{array}$ & \multirow{3}{*}{151} \\
\hline & & & & MvBOx & & $0.12 \mathrm{mAcm}^{-2}(0.65 \mathrm{~V}$ vs NHE) & $\begin{array}{c}\text { Phosphate buffer } \mathrm{pH} \\
\text { 7.4, air-saturated }\end{array}$ & \\
\hline & & & & $R v L C$ & & $0.18 \mathrm{mAcm}^{-2}$ ( $0.45 \mathrm{~V}$ vs NHE) & $\begin{array}{c}\text { Phosphate buffer } \mathrm{pH} \\
\text { 7.4, air-saturated }\end{array}$ & \\
\hline 2014 & $\begin{array}{l}\text { Commercial } \\
\text { MWCNT }\end{array}$ & $\begin{array}{l}\text { Pyrroloquinolin } \\
\text { e quinone }\end{array}$ & DET & MvBOx & $\mathrm{O}_{2}$ & $1.0 \mathrm{~mA} \mathrm{~cm}^{-2}$ (0.1 $\mathrm{V}$ vs $\left.\mathrm{AgAgCl}\right)$ & $\begin{array}{c}\text { Citrate-phosphate buffer } \\
\mathrm{pH} \mathrm{7,} \mathrm{air-saturated}\end{array}$ & 135 \\
\hline 2014 & $\begin{array}{l}\text { Homemade } \\
\text { MWCNT }\end{array}$ & Bis-pyrene-ABTS & MET & $T V L c$ & $\mathrm{O}_{2}$ & $0.8 \mathrm{mAcm}^{-2}$ ( $0.3 \vee$ vs SCE $)$ & $\begin{array}{l}\text { Phosphate buffer } \mathrm{pH} \\
\text { 5.0, } \mathrm{O}_{2} \text {-saturated }\end{array}$ & 86 \\
\hline 2015 & $\begin{array}{c}\text { Commercial } \\
\text { MWCNT }\end{array}$ & $\begin{array}{l}\text { Pyrenemethyl } \\
\text { anthracene }\end{array}$ & DET & MvBOx & $\mathrm{O}_{2}$ & $0.06 \mathrm{mAcm}^{-2}(0.1 \mathrm{~V}$ vs $\mathrm{AgAgCl})$ & Synthetic tears $\mathrm{pH} 7.4$ & 122 \\
\hline 2015 & $\begin{array}{l}\text { Homemade } \\
\text { MWCNT }\end{array}$ & $\begin{array}{l}\text { Pyrene- } \\
\text { norbornene }\end{array}$ & DET & $T V L C$ & $\mathrm{O}_{2}$ & $1.1 \mathrm{mAcm}^{-2}$ (0.4 V vs SCE) & $\begin{array}{l}\text { Phosphate buffer } \mathrm{pH} \\
5.0, \mathrm{O}_{2} \text {-saturated }\end{array}$ & 154 \\
\hline 2015 & $\begin{array}{l}\text { Homemade } \\
\text { MWCNT }\end{array}$ & - & DET & PsLc & $\mathrm{O}_{2}$ & $0.12 \mathrm{mAcm}^{-2}$ (0.4 V vs SCE) & $\begin{array}{l}\text { Culture supernatant } \mathrm{pH} \\
5 \\
\end{array}$ & 157 \\
\hline 2015 & $\begin{array}{c}\text { Homemade } \\
\text { MWCNT }\end{array}$ & Bis-pyrene-ABTS & MET & $\begin{array}{l}\mathrm{HRP}, \\
\mathrm{GOx}\end{array}$ & $\begin{array}{l}\text { Glucose, } \\
\mathrm{O}_{2}, \mathrm{H}_{2} \mathrm{O}_{2} \\
\end{array}$ & $1.1 \mathrm{mAcm}^{-2}$ (0.1 V vs SCE) & Phosphate buffer $\mathrm{pH} 7.4$ & 95 \\
\hline 2015 & $\begin{array}{c}\text { Commercial } \\
\text { MWCNT }\end{array}$ & - & DET & TVLc & $\mathrm{O}_{2}$ & $15 \mu \mathrm{Acm}^{-2}(0.4 \mathrm{~V} \text { vs } \mathrm{AgAgCl})^{[i i]}$ & Phosphate buffer $\mathrm{pH} 7.4$ & 128 \\
\hline 2016 & $\begin{array}{c}\text { Homemade } \\
\text { MWCNT }\end{array}$ & $\begin{array}{l}\text { Pyrene-NHS- } \\
\text { norbornene }\end{array}$ & DET & TvLc & $\mathrm{O}_{2}$ & $0.17 \mathrm{mAcm}^{-2}$ (0.25 V vs AgAgCl) & $\begin{array}{c}\text { Phosphate buffer } \mathrm{pH} \\
5.0, \mathrm{O}_{2} \text {-saturated }\end{array}$ & 85 \\
\hline \multirow{2}{*}{2016} & \multirow{2}{*}{$\begin{array}{c}\text { Commercial } \\
\text { MWCNT }\end{array}$} & \multirow{2}{*}{$\begin{array}{l}\text { Pyrroloquinolin } \\
\text { e quinone }\end{array}$} & \multirow{2}{*}{ DET } & \multirow{2}{*}{ MvBOx } & \multirow{2}{*}{$\mathrm{O}_{2}$} & $0.5 \mathrm{mAcm}^{-2}(0.3 \mathrm{~V}$ vs $\mathrm{AgAgCl})$ & Human urine & \multirow{2}{*}{134} \\
\hline & & & & & & $0.7 \mathrm{mAcm}^{-2}(0.45 \mathrm{~V}$ vs $\mathrm{AgAgCl})$ & Human saliva & \\
\hline 2017 & $\begin{array}{l}\text { Homemade } \\
\text { MWCNT }\end{array}$ & Protoporphyrin & DET & MvBOx & $\mathrm{O}_{2}$ & $1.3 \mathrm{mAcm}^{-2}(0.4 \mathrm{~V}$ vs SCE$)$ & $\begin{array}{l}\text { Phosphate buffer } \mathrm{pH} \\
7.0, \mathrm{O}_{2} \text {-saturated }\end{array}$ & 40 \\
\hline 2017 & $\begin{array}{l}\text { Homemade } \\
\text { MWCNT }\end{array}$ & - & DET & TvLc & $\mathrm{O}_{2}$ & $0.3 \mathrm{mAcm}^{-2}(0.2 \mathrm{~V}$ vs AgAgCl$)$ & $\begin{array}{c}\text { Acetate buffer } \mathrm{pH} 5.5 \text {, } \\
\mathrm{O}_{2} \text {-saturated }\end{array}$ & 138 \\
\hline \multirow{2}{*}{2018} & $\begin{array}{l}\text { Homemade } \\
\text { MWCNT }\end{array}$ & \multirow{2}{*}{$\begin{array}{c}\text { Heme- } \\
\text { protoporphyrin }\end{array}$} & \multirow{2}{*}{ DET } & \multirow{2}{*}{ MvBOx } & \multirow{2}{*}{$\mathrm{O}_{2}$} & $1.3 \mathrm{mAcm}^{-2}$ (0.3 V vs SCE) & \multirow{2}{*}{$\begin{array}{l}\text { Phosphate buffer } \mathrm{pH} \\
\text { 7.0, } \mathrm{O}_{2} \text {-saturated }\end{array}$} & 99 \\
\hline & $\begin{array}{l}\text { Commercial } \\
\text { MWCNT }\end{array}$ & & & & & $0.7 \mathrm{mAcm}^{-2}(0.2 \mathrm{~V}$ vs SCE $)$ & & J \\
\hline
\end{tabular}

Estimated from reported geometric electrode areas of [i] $0.25 \mathrm{~cm}^{2}$ and [ii] $2 \mathrm{~cm}^{2}$.

2D 'fan'-shaped paper-based device. ${ }^{61}$

Lisdat and coworkers also developed buckypaper MvBOxbased biocathodes using buckypaper (from Buckeye Composites). ${ }^{134-135}$ In this work, PQQ cofactor and MvBOx were adsorbed and crosslinked to the electrode by EDC/NHS coupling chemistry. Interestingly, the PQQ was used as a DET promoter (not a mediator) for BOx bioelectrocatalysis. High catalytic currents up to $1.0 \mathrm{mAcm}^{-2}$ were observed at $0.1 \mathrm{~V}$ vs. $\mathrm{Ag} / \mathrm{AgCl}$ in air-saturated buffer solution. ${ }^{135}$ In contrast to previous studies, the authors observed a weak diffusion 
limitation for the oxygen reduction peak in voltammograms, a phenomenon attributed to fast gaseous oxygen diffusion at the buckypaper electrode interface. In a second publication, the authors reported that oxygen reduction is strongly affected in human urine, compared to buffer solution, and only becomes significant at low potentials $\leq 0.32 \mathrm{~V}$ vs. $\mathrm{Ag} / \mathrm{AgCl} .{ }^{134}$ Oxygen reduction in urine was less influenced by interfering substances.

Pankratov et al. investigated homemade MWCNT buckypaper biocathodes modified with different MCOs enzymes: MvBOx, laccase from Trametes hirsuta (ThLC), and laccase from Rhus vernicifera $(R v L C) .{ }^{151}$ The investigations were focused on the use of many different types of CNTs, onset potentials, catalytic currents, $\mathrm{pH}$, stability, and catalytic performance. Maximum limiting catalytic currents in the range of 120 to $220 \mathrm{\mu Acm}^{-2}$ were observed using bioelectrodes prepared from acid-treated CNTs. The authors showed that buckypaper biocathodes gave 10-fold higher catalytic currents compared to spectrographic graphite biocathodes under the same conditions. One observation was that fungal RvLc and MvBOx biocathodes showed high bioelectrocatalytic activity at near neutral conditions ( $\mathrm{pH} 6$ to 8) whereas plant-based ThLc anodes were inactive under these conditions but highly active between $\mathrm{pH} 4$ to 6 . The ThLc biocathode, for example, would therefore not be appropriate for implantable biofuel cells in human blood but could be exploited, for example, on the skin where the optimal $\mathrm{pH}$ is 5.5 .

Minteer and coworkers developed commercial buckypaper (from Buckeye Composites, $27 \mathrm{gsm}$ ) modified with 1pyrenemethyl anthracene-2-carboxylate, Nafion binder and MvBOx, and bonded to a contact lens. ${ }^{122}$ This electrode design represented an important step towards wearable self-powered contact lenses and ocular devices. MvBOx seems to be a better choice compared to $T V L c$ for operation in tear fluid as it has higher activity at neutral $\mathrm{pH}$ and less sensitivity to chloride (tear fluid has a high chloride concentration and a typical $\mathrm{pH}$ range of 6.5 to 7.6). ${ }^{152}$ Pendant anthracene groups presence on the MWCNTs were used for orienting the enzyme via the hydrophobic pocket of the enzyme for better DET, as reported previously. ${ }^{96,153}$ In synthetic tear solution, a catalytic current density of $60 \mu \mathrm{Acm}^{-2}$ at $0 \mathrm{~V}$ vs. $\mathrm{Ag} / \mathrm{AgCl}$ was observed. Removal of ascorbate from the tear solution resulted in a catalytic current increase of $c a .20 \mathrm{\mu Acm}^{-2}$. Ascorbate oxidation can therefore be a significant interference at $M v B O x$ biocathodes.

Gross et al. also exploited $M v B O x$ as the biocatalyst for construction of homemade MWCNT buckypaper biocathodes. ${ }^{40}$ Protoporphyrin was embedded into the homemade buckypaper via $\pi-\pi$ stacking interactions to promote DET with the enzyme. Well-defined voltammetry and maximum limiting currents of $c a .1 .3 \mathrm{mAcm}^{-2}$ were observed at high potentials close to the ideal thermodynamic reduction potential for oxygen. The high performance is consistent with effective enzyme wiring, high conductivity, fast mass transport and fast heterogeneous electron transfer at the surface. The bioelectrode retained $c a$. $73 \%$ of its initial activity after 24 days and hence demonstrated excellent stability to storage and periodic testing. Very recently, Cosnier and coworkers further developed homemade MWCNT buckypaper electrodes modified with protoporphyrin (hemin). A direct comparison between homemade and commercial MWCNT (from Buckeye Composites) electrodes with immobilized MvBOx under various conditions was explored. ${ }^{99}$ This work demonstrated catalytic currents for $\mathrm{O}_{2}$ reduction up to $0.7 \mathrm{mAcm}^{-2}$ at $0.2 \mathrm{~V}$ vs. SCE and $1.3 \mathrm{mAcm}^{-2}$ at $0.3 \mathrm{~V}$ vs. SCE for commercial and homemade buckypaper, respectively.

The fungal laccase, $T V L c$, has been the most frequently used biocatalyst for buckypaper biocathodes. Katz and coworkers established laccase-based biocathodes for implanted biofuel cells in various organisms as well as oranges. ${ }^{41,124-128}$ In these reports, commercial MWCNT buckypaper (from Buckeye Composites) was modified with PBSE crosslinker for covalent immobilization of the enzyme via amide bond formation with protein residues in the enzyme. ${ }^{41,62,124-128}$ Half-cell characterization experiments performed in aqueous buffer and in artificial physiological fluid demonstrated the possibility to achieve in excess of $0.1 \mathrm{mAcm}$ 2 at $0.4 \mathrm{~V}$ vs. $\mathrm{Ag} / \mathrm{AgCl} .{ }^{41,62,124,128} \mathrm{Hou}$ and Liu also recently developed TVLc-based MWCNT buckypaper biocathodes and tested them in aqueous buffer solution. ${ }^{138}$ Homemade buckypapers were prepared and modified with PBSE crosslinker for immobilization of the laccase. Maximum catalytic currents up to $0.3 \mathrm{mAcm}^{-2}$ at $0.2 \mathrm{~V}$ vs. $\mathrm{Ag} / \mathrm{AgCl}$ were observed at $\mathrm{pH} 5.5$ and the biocathode retained $73 \%$ of its catalytic activity after 3 days.

Bourourou et al. developed an elegant approach to high performance MWCNT buckypaper TVLc-based biocathodes. The buckypaper was modified with bis-pyrene-ABTS molecules which acted as both a redox mediator and a nanotube crosslinker. ${ }^{86}$ In one example, the buckypaper was saturated with bis-pyrene-ABTS molecules such that many pyrene groups were freely available for interaction with the hydrophobic pocket of the enzyme (close to the T1 Cu "control centre") for improved catalytic currents. A maximum current density of $0.42 \mathrm{mAcm}^{-2}$ at $0.3 \mathrm{~V}$ vs. SCE was observed for the optimized bis-pyrene-ABTS modified bioelectrode with immobilized TVLC. Interestingly, the authors showed that using laccase in solution, and not on the surface of electrode, increased catalytic currents by 2 -fold up to $0.8 \mathrm{mAcm}^{-2}$ at $0.3 \mathrm{~V}$ vs. SCE. ${ }^{86}$ Use of enzyme in solution is not easily suited to in-vivo applications but this is nevertheless a curious result. In later studies, Cosnier and coworkers reported new methods for fabricating mechanically-enhanced MWCNT buckypaper biocathodes based on 'precision' polynorbornene polymers. ${ }^{85,154}$ In the first report, a linear homopolymer with pyrene groups was incorporated in the buckypaper to significantly improve its flexibility and handleability. ${ }^{154}$ Cosnier and coworkers subsequently investigated the use of short and long copolymers with random and ordered configurations. The polymer was designed with pyrene groups, for cross-linking, and activated esters, for covalent attachment of enzymes and/or DET promoting molecules. ${ }^{85}$ A 4.5 fold increase in tensile modulus and the tensile strength of buckypaper was observed with incorporation of the copolymer. The best performing biocathode was obtained via covalent attachment 
of anthraquinone to the activated ester groups present in the buckypaper. The anthraquinone functionality was used to facilitate the effective orientation of laccase via its hydrophobic pocket. ${ }^{153,155}$ The bioelectrode delivered current densities up to $0.17 \mathrm{mAcm}^{-2}$ at $0.25 \mathrm{~V}$ vs. $\mathrm{Ag} / \mathrm{AgCl}$ and good stability with $\sim 53 \%$ of the initial activity remaining after 24 days. ${ }^{85}$

Umasankar et al. developed homemade SWCNT buckypaper TVLc-based biocathodes modified with catalytic layers of either vertically-aligned carbon nanosheets or MWCNTs. ${ }^{156}$ The TVLC enzyme was immobilized via PBSE crosslinker. A detailed comparison of oxygen reduction activity at SWCNT buckypaper and Toray paper bioelectrodes modified with either carbon nanosheets or MWCNTs was reported. The best performing electrode for oxygen reduction was the SWCNT buckypaper modified with carbon nanosheets. The performance enhancement was attributed to the open planar structure of the nanosheets (as opposed to the closed tubular structure of nanotubes), higher surface area, and abundance of graphene edge plains for fast electron transfer. A maximum catalytic current density of $1.1 \mathrm{mAcm}^{-2}$ fafter background subtraction + was achieved at the carbon nanosheet modified buckypaper, before the experiment became limited by oxygen.

Fokina et al. explored an eco-friendly mediatorless approach to buckypaper bioelectrodes in which the fungal laccase from Pycnoporus sanguineus (PsLc) was used instead of TVLC. ${ }^{157}$ In contrast to TVLC, PsLc does not require a synthetic growth medium and $\mathrm{CuSO}_{4}$ for induction of the enzyme, and hence is more convenient to obtain. At pH 5, using homemade MWCNT buckypapers as reported previously, ${ }^{67}$ the $T V$ Lc-based bioelectrode in supernatant solution exhibited a current density of $115 \mu \mathrm{Acm}^{-2}$ at $0.4 \mathrm{~V}$ vs. SCE at $\mathrm{pH}$ 5. However, the laccase activity was partially inhibited at higher $\mathrm{pH}^{\prime} \mathrm{s}$, with the catalytic currents falling to $30.1 \mu \mathrm{Acm}^{-2}$ and $2.8 \mu \mathrm{Acm}^{-2}$ at $\mathrm{pH} 6$ and $\mathrm{pH} 7$ respectively, thus limiting this electrode design for application at physiological $\mathrm{pHs}$.

Elouarzaki et al. proposed an unconventional biocathode with a 'bi-enzyme cascade' design in which no MCO enzyme was used. ${ }^{95}$ MWCNT buckypaper was first modified with bispyrene-ABTS ${ }^{86}$ then modified with GOx, horseradish peroxidase (HRP), and a polymerized 'biocompatible' polypyrrole-concanavalin A matrix. Reduction of $\mathrm{H}_{2} \mathrm{O}_{2}$ was achieved in the presence of glucose and relied on the enzymatic reduction of oxygen to $\mathrm{H}_{2} \mathrm{O}_{2}$ by $\mathrm{GOx}$ during enzymatic glucose oxidation. The hydrogen peroxide was electroenzymatically reduced to water by the horseradish peroxidase via the bis-pyrene-ABTS mediator. In the presence of glucose and in-situ generated hydrogen peroxide, a stable catalytic current of $1.1 \mathrm{mAcm}^{-2}$ at $0.1 \mathrm{~V}$ vs. SCE was obtained..$^{95}$ Good stability was also exhibited with $c a .64 \%$ of the initial activity remaining after 15 days.

\section{Enzymatic biofuel cells}

The first buckypaper-based enzymatic biofuel cells were developed by Katz and coworkers for implanted energy harvesting. ${ }^{18,41,124-128}$ Biofuel cells were constructed with the same PQQGDH-based bioanode, for glucose oxidation, and

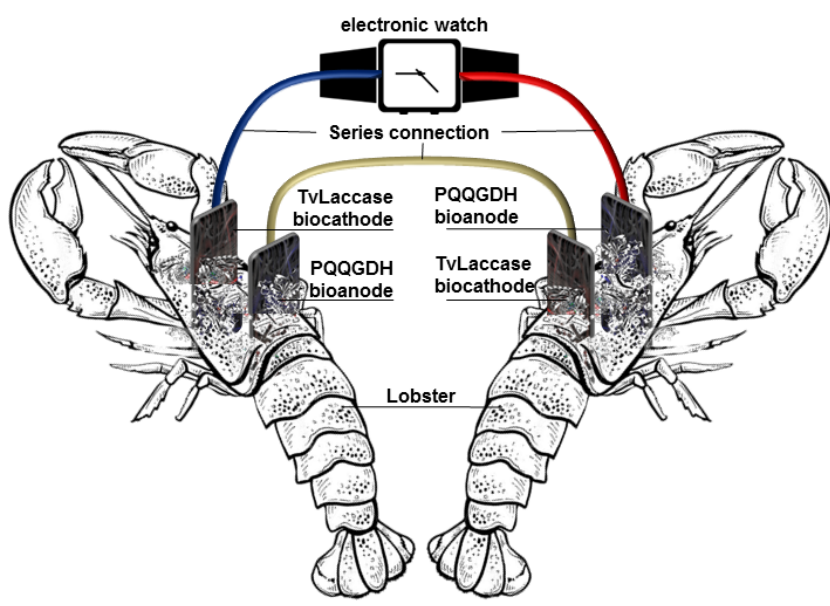

Figure 4: Schematic presentation of the connection of two biofuel cells, implanted in two lobsters, in series, leading to a doubled voltage output.

TvLc-based biocathode, for oxygen reduction. For the biofuel cells implanted in an orange, a dual enzyme bioanode with PQQGDH and FADFDH was used for oxidation of glucose and fructose in place of the PQQGDH-only bioanode. ${ }^{128}$ The key figures of merit for the implanted biofuel cells of Katz and coworkers, as well as the biofuel cells developed for portable and wearable applications, are summarized in Table 3.

Halámková demonstrated the concept of a membraneless glucose $/ \mathrm{O}_{2}$ buckypaper biofuel cell harvesting energy in-vivo in a living creature. ${ }^{41}$ The electrodes were inserted into the hemolymph (snail's blood) via the shell. Impressively, either feeding the snail, or allowing the snail to rest for 30-60 min, permitted the power output to be restored via slow glucose diffusion and metabolic processes. The implanted biofuel cell delivered an open circuit voltage (OCV) of $0.53 \mathrm{~V}$ and a power output of $7.45 \mu \mathrm{W}\left(30 \mu \mathrm{Wcm}^{-2}\right)$ vs. a $20 \mathrm{k} \Omega$ resistance with $20 \%$ variability. Stable operation over a period of 2 weeks was demonstrated, suggesting excellent stability and limited inhibition by biofouling.

A problem concerning the integration of biofuels with microelectronic devices is that the output / OCV of biofuel cells is far smaller (up to around $0.8 \mathrm{~V}$ ) than most microelectronic devices which require at least 1 to $3 \mathrm{~V}$ input voltage for operation. Szczupak et al. started to address this issue by connecting biofuel cells implanted in the hemolymph of hardshelled clams in series. ${ }^{124} \mathrm{~A}$ biofuel cell in a single organism at $\mathrm{pH} 7$ to 8 delivered an OCV of 0.3 to $0.4 \mathrm{~V}$ and power output of $10 \mu \mathrm{W}\left(40 \mu \mathrm{Wcm}^{-2}\right)$ vs. a $3 \mathrm{k} \Omega$ resistance with 3 -fold variability and the capability to operate for 5 days. Connection in series of three clams significantly increased the OCV to $0.8 \mathrm{~V}$ and produced a power of $5.2 \mu \mathrm{W}\left(21 \mu \mathrm{Wcm}^{-2}\right)$. In the parallel configuration, larger power outputs up to $37 \mu \mathrm{W}\left(148 \mu \mathrm{Wcm}^{-2}\right)$ were obtained with OCV of 0.3 to $0.4 \mathrm{~V}$. Powering of an electronic device from implanted biofuel cells was demonstrated by accumulating energy in a $1 \mathrm{~F}$ capacitor during a period of 1 hour, followed by a current discharge to produce energy to turn an electric motor.

Castorena-Gonzalez et al. reported the first results for a membraneless biofuel cell operating in blood in direct 
Table 3: Figures of merit for enzymatic buckypaper biofuel cells

\begin{tabular}{|c|c|c|c|c|c|c|c|c|c|c|c|}
\hline Year & Fuel Cell & Buckypaper & Anode & Cathode & $\begin{array}{l}\text { Electron } \\
\text { Transfer }\end{array}$ & Substrate & ocv & Power & $\begin{array}{l}\text { Power } \\
\text { Density }\end{array}$ & Stability & Ref \\
\hline 2012 & $\begin{array}{l}\text { Implanted } \\
\text { in snails }\end{array}$ & Commercial & PQQGDH & TVLC & $\begin{array}{l}\text { Anode: } \mathrm{DET} \\
\text { Cathode: DET }\end{array}$ & $\begin{array}{l}\text { Anode: glucose } \\
\text { Cathode: } \mathrm{O}_{2}\end{array}$ & $0.53 \mathrm{~V}$ & $7.45 \mu \mathrm{W}$ & $30 \mu \mathrm{Wcm}^{-2}$ & 2 weeks & 41 \\
\hline 2012 & $\begin{array}{l}\text { Implanted } \\
\text { in clams }\end{array}$ & Commercial & PQQGDH & TVLC & $\begin{array}{l}\text { Anode: DET } \\
\text { Cathode: DET }\end{array}$ & $\begin{array}{l}\text { Anode: glucose } \\
\text { Cathode: } \mathrm{O}_{2}\end{array}$ & $\begin{array}{c}0.8 \mathrm{~V} \text { ( } 3 \text { fuel cells in series }) \\
0.36 \mathrm{~V}(3 \text { fuel cells in parallel })\end{array}$ & $\begin{array}{l}5.2 \mu \mathrm{W} \\
37 \mu \mathrm{W}\end{array}$ & $\begin{array}{l}21 \mu \mathrm{Wcm}^{-2[i]} \\
148 \mu \mathrm{Wcm}^{-2[i]}\end{array}$ & 3-5 days & 124 \\
\hline 2013 & $\begin{array}{l}\text { Implanted } \\
\text { in rats }\end{array}$ & Commercial & PQQGDH & TVLC & $\begin{array}{l}\text { Anode: DET } \\
\text { Cathode: DET }\end{array}$ & $\begin{array}{c}\text { Anode: glucose } \\
\text { Cathode: } \mathrm{O}_{2}\end{array}$ & $0.14 \mathrm{~V}$ & $0.35 \mu \mathrm{W}$ & $0.2 \mu \mathrm{Wcm}^{-2[i]]}$ & - & 125 \\
\hline 2013 & $\begin{array}{l}\text { Implanted } \\
\text { in lobsters }\end{array}$ & Commercial & PQQGDH & $T V L c$ & $\begin{array}{l}\text { Anode: DET } \\
\text { Cathode: DET }\end{array}$ & $\begin{array}{l}\text { Anode: glucose } \\
\text { Cathode: } \mathrm{O}_{2}\end{array}$ & $0.54 \mathrm{~V}$ & $160 \mu \mathrm{W}$ & $640 \mu \mathrm{Wcm}-2[i]$ & $\begin{array}{l}\text { A few } \\
\text { hours }\end{array}$ & 126 \\
\hline 2013 & $\begin{array}{l}\text { Human serum } \\
\text { with flow }\end{array}$ & Commercial & PQQGDH & TVLC & $\begin{array}{l}\text { Anode: DET } \\
\text { Cathode: DET }\end{array}$ & $\begin{array}{c}\text { Anode: glucose }\left(6.4 \mathrm{mmolL}^{-1}\right) \\
\text { Cathode: } \mathrm{O}_{2}\end{array}$ & $0.47 \mathrm{~V}$ & - & - & 5 hours & 127 \\
\hline 2014 & $\begin{array}{l}\text { Phosphate buffer } \\
\text { pH } 7.2\end{array}$ & Homemade & GOx & MvBOx & $\begin{array}{l}\text { Anode: } \mathrm{MET} \\
\text { Cathode: } \mathrm{MET}\end{array}$ & $\begin{array}{l}\text { Anode: glucose }\left(5 \mathrm{mmolL}^{-1}\right) \\
\text { Cathode: } \mathrm{O}_{2} \text { (saturated) }\end{array}$ & $0.55 \mathrm{~V}$ & - & $26 \mu \mathrm{Wcm}^{-2}$ & - & 159 \\
\hline 2014 & $\begin{array}{l}\text { Citrate-phosphate } \\
\text { buffer } \mathrm{pH} 7, \mathrm{CaCl}_{2}\end{array}$ & Commercial & PQQGDH & MvBOx & $\begin{array}{l}\text { Anode: DET } \\
\text { Cathode: DET }\end{array}$ & $\begin{array}{l}\text { Anode: glucose }\left(10 \mathrm{mmolL}^{-1}\right) \\
\text { Cathode: } \mathrm{O}_{2} \text { (air-saturated) }\end{array}$ & $c a .0 .7 \mathrm{~V}$ & $\begin{array}{l}5.4-12 \\
\mu \mathrm{W}^{\text {[iii] }}\end{array}$ & $107 \mu \mathrm{Wcm}^{-2}$ & 3 days & 135 \\
\hline 2014 & $\begin{array}{l}\text { Gatorade drink } \\
\text { with } \mathrm{NAD}^{+}\end{array}$ & Commercial & NADGDH & MvBOx & $\begin{array}{l}\text { Anode: } \mathrm{DET} \text { [vii] } \\
\text { Cathode: } \mathrm{DET}\end{array}$ & $\begin{array}{c}\text { Anode: mono/disaccharides } \\
\text { Cathode: } \mathrm{O}_{2}\end{array}$ & $1.8 \mathrm{~V}$ ( 3 fuel cells in series) & - & $\begin{array}{c}0.18 \mathrm{~mW} \mathrm{mg}^{-1} \\
\mathrm{GDH}\end{array}$ & 16 days & 116 \\
\hline 2015 & $\begin{array}{l}\text { Implanted } \\
\text { in oranges }\end{array}$ & Commercial & $\begin{array}{l}\text { PQQGDH } \\
\text { FADFDH }\end{array}$ & TVLC & $\begin{array}{l}\text { Anode: DET } \\
\text { Cathode: DET }\end{array}$ & $\begin{array}{c}\text { Anode: glucose/fructose } \\
\text { Cathode: } \mathrm{O}_{2}\end{array}$ & $0.6 \mathrm{~V}$ & $670 \mu \mathrm{W}$ & $90 \mu \mathrm{Wcm}-2[i v]$ & $\geq 6$ hours & 128 \\
\hline 2015 & $\begin{array}{l}\text { Synthetic tears } \\
\text { pH } 7.4\end{array}$ & Commercial & NADLDH & MvBOx & $\begin{array}{l}\text { Anode: } \mathrm{DET}[\text { vii] } \\
\text { Cathode: } \mathrm{DET}\end{array}$ & $\begin{array}{c}\text { Anode: lactate }\left(3 \mathrm{mmolL}^{-1}\right) \\
\text { ascorbate. Cathode: } \mathrm{O}_{2}\end{array}$ & $0.41 \mathrm{~V}$ & $3 \mu \mathrm{W}$ & $8 \mu \mathrm{Wcm}^{-2}$ & 1 day & 122 \\
\hline 2016 & $\begin{array}{l}\text { Human urine and } \\
\text { saliva }\end{array}$ & Commercial & PQQGDH & MvBOx & $\begin{array}{l}\text { Anode: DET } \\
\text { Cathode: DET }\end{array}$ & $\begin{array}{l}\text { Anode: glucose } \\
\text { Cathode: } \mathrm{O}_{2}\end{array}$ & $\begin{array}{l}0.4 \mathrm{~V} \text { (urine) } \\
0.67 \mathrm{~V} \text { (saliva) }\end{array}$ & - & $\begin{array}{l}13 \mu \mathrm{Wcm}^{-2} \\
19 \mu \mathrm{Wcm}^{-2}\end{array}$ & - & 134 \\
\hline 2016 & $\begin{array}{c}\text { Phosphate buffer } \\
\mathrm{pH} 7, \mathrm{NAD}^{+}\end{array}$ & Homemade & NADGDH & MvBOx & $\begin{array}{l}\text { Anode: DET[vii] } \\
\text { Cathode: DET }\end{array}$ & $\begin{array}{l}\text { Anode: glucose (saturated) } \\
\text { Cathode: } \mathrm{O}_{2} \text { (saturated) }\end{array}$ & $0.62 \mathrm{~V}$ & $141 \mu \mathrm{W}^{[v]}$ & $470 \mu \mathrm{Wcm}^{-2}$ & 2 days & 123 \\
\hline 2016 & $\begin{array}{l}\text { Buffer pH 7.5, } \\
\text { NAD }^{+} \text {and flow }\end{array}$ & Commercial & NADGDH & MvBOx & $\begin{array}{l}\text { Anode: } \mathrm{DET}^{[\text {vii] }} \\
\text { Cathode: } \mathrm{DET}\end{array}$ & $\begin{array}{l}\text { Anode: glucose }\left(0.1 \mathrm{molL}^{-1}\right) \\
\text { Cathode: } \mathrm{O}_{2}\end{array}$ & $0.59 \mathrm{~V}$ & $13.1 \mathrm{~mW}$ & $1.07 \mathrm{mWcm}^{-2}$ & 3 days & 61 \\
\hline 2017 & $\begin{array}{l}\text { Mcllvaine buffer } \\
\mathrm{pH} 7\end{array}$ & Homemade & FADGDH & MvBOx & $\begin{array}{l}\text { Anode: } \mathrm{MET} \\
\text { Cathode: } \mathrm{DET}\end{array}$ & $\begin{array}{l}\text { Anode: glucose (saturated) } \\
\text { Cathode: } \mathrm{O}_{2} \text { (saturated) }\end{array}$ & $0.67-0.74 \mathrm{~V}$ & $510 \mu \mathrm{W}^{[\mathrm{vi}]}$ & $650 \mu \mathrm{Wcm}^{-2}$ & - & 40 \\
\hline 2017 & $\begin{array}{c}\text { Acetate buffer } \mathrm{pH} \\
5.5\end{array}$ & Homemade & FADGDH & TVLC & $\begin{array}{l}\text { Anode: } \mathrm{MET} \\
\text { Cathode: } \mathrm{DET}\end{array}$ & $\begin{array}{l}\text { Anode: glucose }\left(30 \mathrm{mmolL}^{-1}\right) \\
\text { Cathode: } \mathrm{O}_{2} \text { (saturated) }\end{array}$ & $1.4 \mathrm{~V}$ ( 2 fuel cells in series) & - & $326 \mu \mathrm{Wcm}^{-2}$ & 7 days & 138 \\
\hline
\end{tabular}

Estimated from reported geometric electrode areas of [i] $0.25 \mathrm{~cm}^{2}$, [ii] $2 \mathrm{~cm}^{2}$, [iii] $0.05-0.11 \mathrm{~cm}^{2}$, [iv] $7.5 \mathrm{~cm}^{2}$, [v] $0.3 \mathrm{~cm}^{2}$, and [vi] $0.785 \mathrm{~cm}^{2}$ electrode area (10 mm diameter). [vii] Pseudo-DET where electron transfer occurs between the electrode and enzyme via unbound NAD coenzyme, facilitated by an electrocatalyst. 
contact with the tissue of a vertebrate animal cremaster muscle, ${ }^{125}$ advancing earlier work in which bioelectrodes implanted in vertebrates were separated by a membrane ${ }^{17}$ or capillary. ${ }^{158}$ The biofuel cell delivered an OCV of $0.14 \mathrm{~V}$ and a maximum power of $c a .0 .35 \mu \mathrm{W}\left(0.175 \mu \mathrm{Wcm}^{-2}\right)$. The lower than expected voltage and current outputs were attributed to the electrodes being in contact with exposed tissue rather than directly immersed in blood. Fuel cell performance was nevertheless comparable to that obtained for other in-vivo operating biofuel cells in rats and rabbits. ${ }^{17,158}$

MacVittie et al. demonstrated the implantation of $z$ buckypaper biofuel cells in the hemolymph of lobsters, ${ }^{126}$ as shown in Figure 4 . For a single lobster, an OCV of $0.54 \mathrm{~V}$ and power output of ca. $0.16 \mathrm{~mW}\left(0.64 \mathrm{mWcm}^{-2}\right.$ vs. a $500 \Omega$ resistance) was delivered. The authors reported that connecting anode-cathode pairs in series in a single living lobster did not work due to a low resistance between them which caused electrical shorting. Implantation and series connection of two biofuel cells in two lobsters doubled the OCV to ca. $1 \mathrm{~V}$ (up to $1.2 \mathrm{~V}$ ), which was sufficient for activating an electronic watch for at least an hour. Series connection of five biofuel cells in five lobsters, in serum, in an artificial capillary vessel, generated an OCV of $2.8 \mathrm{~V}$, therefore meeting the $c a$. $1.4 \mathrm{~V}$ requirement for powering low-power microelectronics devices such as a pacemaker. Sufficient power greater than $90 \mu \mathrm{W}$ was also possible using this setup, which was sufficient to operate a battery-free pacemaker for at least 5 hours. This is a noteworthy achievement but the practicality of connecting multiple human bodies together to power a biomedical device is questionable!

An alternative method to solve the voltage problem is to integrate an off-the-shelf DC-DC boost converter. This permits the voltage to be increased, but, at the expense of a loss in current. This strategy was explored by MacVittie et al. for a biofuel cell in human serum in an artificial human capillary vessel after spiking with glucose. ${ }^{127}$ The biofuel cell generated an OCV in the range of 0.3 to $0.5 \mathrm{~V}$ and a current of $c a .5 \mathrm{~mA}$ (0.83 $\left.\mathrm{mAcm}^{-2}\right)$. This ultimately provided $c a .3 \mathrm{~V}$ and the necessary peak current draw of $100 \mu \mathrm{A}$ for pacemaker operation, as well as the necessary current of $2 \mathrm{~mA}$ to operate the charge pump. To achieve the required current from single biofuel cells, large buckypaper electrodes were cut with a geometrical surface area of $6 \mathrm{~cm}^{2}$. Electrodes with dimensions on the order of a few several $\mathrm{cm}$ 's are approaching the upper limit for a discrete implantable/wearable biofuel cell device.

Many electronic devices operate in a low-power "rest mode" during periods of inactivity to save significantly on energy consumption. For such devices, capacitors or supercapacitors are used to store charge during rest periods and to release energy on demand during "active" mode periods. MacVittie and coworkers explored this concept by integrating a biofuel cell with a charge pump DC-DC converter system and a $1 \mathrm{mF}$ supercapacitor to power a wireless transmitting device. ${ }^{128} \mathrm{An}$ OCV of $c a .0 .6 \mathrm{~V}$ and a power output of $90 \mu \mathrm{Wcm}^{-2}$ vs. a $200 \Omega$ resistance were delivered using glucose, fructose and oxygen as the fuels and oxidant. The wireless transmitter was activated by extracting power from

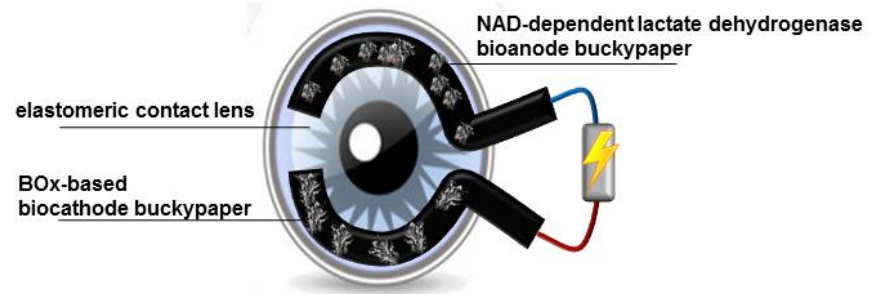

Figure 5: Sketch of a buckypaper-based enzymatic biofuel cell in a contact lens.

the biofuel cell and the periodic release of energy to drive the microcontroller for sample measurement and wireless transmission. As the capacitor accumulated energy during rest mode, only $7 \mu \mathrm{A}$ of current was drawn. The charge-discharge cycle was continuously repeated to ensure a periodic supply of energy over several hours, therefore offering great promise for the powering of future devices which require short periodic "on" periods. Future devices such as chemical sensors which take sample measurements once a day rather than continuously may be envisaged, for example.

Bunte et al. reported the assembly of a glucose $/ \mathrm{O}_{2}$ biofuel cell from homemade buckypapers with a BOx/ABTS-based buckypaper biocathode and a GOx/Fc polymer-based bioanode. ${ }^{159}$ Biofuel cell reproducibility and substrate concentration effects were explored. ${ }^{159} \mathrm{An} \mathrm{OCV}$ of $0.55 \mathrm{~V}$ and power output of $26 \mu \mathrm{Wcm}^{-2}$ at $0.2 \mathrm{~V}$ was achieved in $\mathrm{pH} 7.2$ oxygen-saturated phosphate buffer with $5 \mathrm{mmol} \mathrm{L}^{-1}$ glucose. Scherbahn et al. reported a convenient biofuel cell design based on DET enzyme-electrode interfaces. ${ }^{135}$ The fuel cell with a BOx/PQQ-based biocathode and a PQQGDH/PABMSA/PQQ-based anode delivered an OCV of $c a$. $0.7 \mathrm{~V}$ and power output of $107 \mu \mathrm{Wcm}^{-2}$ at $0.5 \mathrm{~V}$ in $\mathrm{pH} 7$ airsaturated buffer solution with $10 \mathrm{mmol} \mathrm{L}^{-1}$ glucose and $1 \mathrm{mmol}$ $\mathrm{L}^{-1} \mathrm{CaCl}_{2}$. An important observation from this work was that EDC/NHS crosslinking of the PQQGDH enzyme at the anode improved power output stability by 2 -fold compared to when the electrode was not crosslinked, suggesting that enzyme crosslinking should not be overlooked when constructing biofuel cells (which it often is). Lisdat and coworkers also tested the same type of biofuel cell in human body fluids and demonstrated that lower output is observed in these media due to low glucose concentrations and diminished biochemical catalysis due to interfering substances present in the fluids. ${ }^{134}$ For example, $12 \%$ and $18 \%$ of the power output was obtained in urine and saliva, respectively, compared to in buffer solution. The OCV also dropped from $0.71 \mathrm{~V}$ in buffer solution to $0.4 \mathrm{~V}$ in urine and $0.665 \mathrm{~V}$ in urine saliva.

Lalaoui et al. reported methods to improve power outputs by using a non-reagentless buckypaper biofuel cell with an NADGDH-based anode and a BOx-based cathode with $\mathrm{NAD}^{+} / \mathrm{NADH}$ in solution. ${ }^{123} \mathrm{An} \mathrm{OCV}$ of $0.62 \mathrm{~V}$ and maximum power outputs of $0.25 \mathrm{mWcm}^{-2}$ and $0.47 \mathrm{mWcm}^{-2}$ were reported in $5 \mathrm{mmol}^{-1}$ glucose/air and $150 \mathrm{mmol} \mathrm{L}^{-1}$ glucose/oxygen-saturated solutions, respectively. The biofuel cell unfortunately requires cofactor to be added in solution and had limited stability with a $c a$. $30 \%$ loss in power output after only two days of storage. 
Atanassov and coworkers have made good progress towards the development of portable and biodegradable biofuel cells for powering electronic devices (such as a digital clock) for several days from ubiquitous liquid such as Gatorade ${ }^{\circledR} .61,116$ The microfluidic paper system provides a continuous supply of biofuel, cofactor and electrolytes, and doesn't require an energy-consuming electrical pump. ${ }^{140} \mathrm{~A}$ single fuel cell with a buckypaper NADGDH-anode and a Toray paper BOx-cathode maintained $0.62 \mathrm{~V}$ for 6 days and $0.4 \mathrm{~V}$ for 16 days with periodic glucose refuelling. ${ }^{116}$ The assembly of three fuel cells in series delivered an OCV of $1.67 \mathrm{~V}$ and power output of $0.10 \mathrm{~mW} / \mathrm{mg} \mathrm{GDH}$ in buffer solution with $100 \mathrm{mmol}$ $\mathrm{L}^{-1}$ glucose and $50 \mathrm{mmol} \mathrm{L}^{-1} \mathrm{NAD}^{+}$. A larger OCV of $1.8 \mathrm{~V}$ and a power output up $0.18 \mathrm{~mW} / \mathrm{mg} \mathrm{GDH}$ was obtained using the Gatorade drink which contained 3-fold more sugar than the buffer solution, permitting a digital clock to be activated for 9 hours. In later work, Atanassov and coworkers exploited buckypaper at both the cathode and the anode in a paperbased flow biofuel cell with supercapacitive featuresflow. ${ }^{61}$ The biofuel cell comprised an NADGDH-based anode and BOxbased cathode. An impressive practical power output in pulse mode of $1.07 \mathrm{mWcm}^{-2}$ (13.1 mW!) was achieved in $\mathrm{pH} 7.5$ buffer solution with $100 \mathrm{mmol} \mathrm{L}^{-1}$ glucose and $1 \mathrm{mmol} \mathrm{L}^{-1} \mathrm{NAD}^{+}$, which is significantly higher than the power obtained in a stationary single cell ${ }^{116}$ and among the highest power recorded for an enzymatic biofuel cell. Whilst this work demonstrates the powering of small electronic devices from commercial beverages, the need to add $\mathrm{NAD}^{+}$cofactor to the fuel cell restricts its application for implantable and wearable applications.

A promising use of energy harvesting enzymatic biofuel cells is in "smart" or "bionic" contact lenses for applications in human vision and biomedical sensing (Figure 5). ${ }^{160}$ Ocular biofuel cells and glucose-oxidizing bioelectrodes could be used on contact lenses by type I diabetics for non-invasive in-vivo glucose monitoring. ${ }^{117,161}$ This is an exciting possibility for buckypaper materials owing to the need for conductive materials that are lightweight, thin and flexible. Shleev and coworkers initially developed the ocular biofuel cell concept by demonstrating a membraneless biofuel cell operating in basal human lachrymal fluid using nanostructured microbioelectrodes. ${ }^{162}$ A few years later, Minteer and coworkers developed a buckypaper biofuel cell which was successfully integrated on an elastomeric contact lens, benefiting from the shapeability and flexibility of buckypaper. ${ }^{122}$ The biofuel cell, with an NAD-dependent lactate dehydrogenase anode and BOx-based cathode, delivered an OCV of $0.41 \mathrm{~V}$ and a maximum power output of $8 \mu \mathrm{Wcm}^{-2}$ at $0.2 \mathrm{~V}$ in synthetic tear solution with stability of only a few hours. Despite the short term operational stability, the low power could be appropriate for a basic ocular device requiring short bursts of power during a single day. An implantable eye sensor for glaucoma management, for example, requires only 5-6 nW of power at $1.5 \mathrm{~V}$ for operation. ${ }^{163}$ In addition to improving biocompatibility and device fabrication, future work must also address the voltage issue and potential toxicity due to mediator leaching.
Gross et al. reported a reagentless and membraneless buckypaper biofuel cell based on a FADGDH-based anode and BOx-based cathode. ${ }^{40}$ The FAD-dependent dehydrogenase enzyme has become commercially available in recent years and seems to be an excellent enzyme for construction of high power generating glucose $/ \mathrm{O}_{2}$ enzymatic biofuel cells. Advantages include its high activity, tightly bound cofactor, and oxygen insensitivity (see Enzymatic bioanodes section). The dehydrogenase enzymes, NADGDH and PQQGDH, also exhibit oxygen insensitivity, but the redox potential of their cofactors are higher compared to that of FAD, which limits the fuel cell OCV. Bioelectrocatalytic substrate oxidation at low potentials should improve the open circuit voltage of biofuel cells and hence is very attractive. The first buckypaper biofuel cell exploiting an FADGDH anode delivered an OCV between 0.64 and $0.74 \mathrm{~V}$, facilitated by low potential oxidation of glucose, and a power output of $0.65 \mathrm{mWcm}^{-2}$ or $24.07 \mathrm{mWcm}^{-3}$ at $0.5 \mathrm{~V}$ in $\mathrm{pH} 7.4$ oxygen-saturated buffer solution. Short term stability experiments revealed the possibility to draw $500 \mu \mathrm{A}$ for $30 \mathrm{~min}$ with a stable voltage of $0.57 \mathrm{~V}$. As for many of the biofuel cells reported, the cathode was the limiting factor in terms of power output, with dissolved oxygen concentration and mass transport being a major restriction. A further disadvantage of the biofuel cell design developed by Gross et al. is that the FADGDH-based anode showed very poor stability over several days. Use of hydrogels and enzyme cross-linking methods, as well as covalently attached redox mediators, should help to alleviate the bioanode stability issue with FADGDH. Use of rationally engineered proteins may become necessary to achieve sufficient stability for implantable and wearable applications. For example, Sode and Mori have developed methods to produce novel fungal FADGDH enzymes, by replacing specific amino acid residues, with dramatically increased thermal stability. ${ }^{164}$

$\mathrm{Hou}$ and Liu developed membraneless and reagentless glucose $/ \mathrm{O}_{2}$ biofuel cells with a FADGDH-based anode and laccase-based cathode. ${ }^{138} \mathrm{~A}$ single biofuel cell delivered a high OCV of $0.71 \mathrm{~V}$ and a maximum power output of $0.204 \mathrm{mWcm}^{-2}$ at $0.35 \mathrm{~V}$ in oxygen-saturated buffer solution, hence 3 -fold power output lower than the biofuel cell reported by Cosnier and coworkers. ${ }^{40}$ For two biofuel cells connected in series, the OCV doubled to $1.4 \mathrm{~V}$ and the maximum power output increased by a third to $0.326 \mathrm{mWcm}^{-2}{ }^{138}$ Higher power outputs were demonstrated up to $0.608 \mathrm{mWcm}^{-2}$ when the two biofuel cells were integrated with a supercapacitor in a single device. Another attractive feature of the biofuel cell developed by Hou and Liu is that $56 \%$ of its maximal power was observed after 7 days, which appears to highlight the beneficial effect of using a hydrogel encapsulated bioanode.

\section{Buckypaper biocompatibility, toxicity and tissue adhesion}

Prior to introducing a foreign substance into or onto the human body, understanding the organisms' response to it is critical, including the monitoring of irritation and inflammatory reactions and toxicity. With respect to buckypapers, there is widespread concern about the toxicity and cytotoxicity of 
carbon nanotubes with some studies indicating high toxicity and others demonstrating little or no toxic effects to humans. ${ }^{165}$ Assessing and optimizing the biocompatibility of bioelectrodes for implantable and wearable biofuel cells is therefore of paramount importance to prevent unexpected risks to humans and their environment. For accreditation of implantable devices, strict guidelines must be followed to meet safety regulations. Concerning biocompatibility, various factors must be carefully considered including cytotoxicity, irritation and sensitization, systemic toxicity, genotoxicity, carcinogenicity and hemocompatability. ${ }^{166}$

Bellucci et al. in 2009 evaluated the toxicology and biological effects in-vitro and in-vivo of MWCNT buckypaper. ${ }^{167}$ Buckypaper samples did not arouse any serious toxicity except for very limited inflammation. Decreased cell proliferation was observed for human, colorectal, breast and leukemic cells. No effect on the proliferation and viability of normal human muscle cells and dermal fibroblasts was observed, suggesting that buckypaper is a promising material for skin-based applications. An inflammatory response was noted after 2 weeks of implantation in a rat, which was followed by scar fibrosis, suggesting that improvements in biocompatibility would be required for implantable applications.

Zeni et al. investigated the cytotoxicity of 95\% MWCNT buckypaper (from NanoLab Inc.), and observed inhibited cell growth, but no induction of cell death, for stimulated human blood lymphocytes on buckypaper, likely due to cytostatic and cytotoxic events. ${ }^{106}$ This report therefore suggests some safety concern for buckypaper. It is not clear to which extent if the toxicity is due to the carbon nanotubes, the presence of a commercial surfactant, NanoSperse $A Q^{\circledR}$, or the $5 \%$ impurities which included iron catalyst. In a later study on the same type of buckypaper, ${ }^{105}$ cell growth, apoptosis and reactive oxygen species formation were monitored. For three different leukaemia cells and human lymphocytes, the buckypaper reduced cell growth and increased apoptosis, further highlighting biocompatibility issues for this type of buckypaper.

In a complimentary study by Martinelli et al., the adhesion of MWCNT buckypaper to biological tissue was examined. ${ }^{168}$ Peeling and sheer adhesion tests demonstrated that the MWCNT buckypaper (from NanoLab Inc.) was able to strongly adhere to soft and wet tissue from a rabbit abdominal wall. The buckypaper adhesion was found to be much better than that recorded for a commercial prosthetic fabric, thus paving the way for buckypaper to be used an adhesive material invivo, for example, on abdominal prosthetics or subcutaneously. Also in the context of implantable devices, Fishman and coworkers demonstrated that buckypaper had the necessary physical and chemical properties for therapeutic cell transplantation in the eye. ${ }^{55}$ Buckypapers were implanted underneath rabbit retinas and remained attached without edema or inflation for 2 weeks, therefore highlighting the excellent prospects of buckypaper as an artificial membranetype biofuel cell for retinal and iris epithelial cells.

\section{Conclusions}

Over the last 5 to 7 years, the development of carbon nanotube buckypapers for the elaboration of enzymatic bioelectrodes has resulted in substantial developments, not only in bioelectrochemistry, but also in the fields of materials science, biomedical science and catalysis. Buckypaper materials have witnessed great success for construction of bioelectrodes owing to a unique combination of properties such as flexibility, lightweight, high conductivity, high surface area, and high porosity. In addition, in-vivo and in-vitro testing of buckypapers have certainly shown that buckypaper possesses, at least in some cases, attractive biocompatibility, toxicity and tissue adhesion properties. Functional biointerfaces with various electrically wired enzymes via direct and mediated electron transfer strategies have been developed using, in particular, commercially sourced buckypaper. Some of the highest current and power densities to date in the field of enzymatic biofuel cells have been obtained using buckypaper-based bioelectrodes and biofuel cells, respectively. High catalytic current and power outputs up to the $\mathrm{mW}$ range, although typically in the $\mu \mathrm{W}$ range, have been achieved in buffer solutions, which is sufficient to power bioelectronics devices with appropriate power management. Much more research is needed to assess and optimize the actual performance of bioelectrodes and biofuel cells in invitro physiological solutions and in-vivo. Notably, the greatest achievement of buckypaper to date has been in actual implanted energy harvesting devices for device powering from various organisms since 2012 - no other electrode material can boast as much success in the field of biofuel cells. The realization of such devices as replacements for batteries in implantable and portable devices is still far away from commercial in-vivo applications with biocompatibility, toxicity, current outputs, power outputs and operational stability clearly being major issues to address. Better performing functional materials are envisaged through careful design and bottom-up fabrication of buckypapers in the laboratory with the best control possible over their properties. For example, we believe that future buckypaper biofuel cells must employ stable, permeable and biocompatible encapsulation layers, for example, based on redox polymers and hydrogels. Covalent surface chemistry and cross-linking approaches also seem necessary to facilitate the stable attachment of biocatalytic components to the electrodes for longer term operation. In addition, solutions will be required to address mass transport limitations and electrode deactivation effects in physiological solutions. Concerning future research on buckypaper for biofuel cell applications, it is essential that researchers provide accurate details relating to the buckypaper materials used, including basic physical details such as thickness, conductivity, roughness, and wettability. With respect to fabrication methods, detailed experimental protocols and conditions, including the specific type of carbon nanotubes used, are also necessary. This information will serve as a comparable metric to help with the reproduction and improvement of buckypapers for the development of biofuel cells as well as 
other advanced energy generation and energy storage devices. With all of this in mind, and considering the excellent progress that has been made to date, there should be little doubt that buckypaper will have an important role to play in future implantable, wearable and portable bioelectronics devices.

\section{Conflicts of interest}

There are no conflicts to declare.

\section{Acknowledgements}

This work was supported by ANR-15-JTIC-0002-01 and Polynat Carnot Institute (ANR-11-CANR-0007-01). We are grateful to Miss Xiaohong Chen and for provision of SEM images.

\section{References}

1 S. Cosnier, A. Le Goff and M. Holzinger, Electrochem. Commun., 2014, 38, 19-23.

2 J. O. Mills, A. Jalil and P. E. Stanga, Eye, 2017, 31, 1383-1398.

3 K. Famm, B. Litt, K. J. Tracey, E. S. Boyden and M. Slaoui, Nature, 2013, 496, 159.

4 A. J. Bandodkar and J. Wang, Trends Biotechnol., 2014, 32, 363-371.

5 M. Haghi, K. Thurow and R. Stoll, Healthc. Inform. Res., 2017, 23, 4-15.

6 B. A. Amar, B. A. Kouki and H. Cao, Sensors, 2015, 15, 2888928914.

7 A. S. Y. Poon, in Implantable Bioelectronics, Wiley-VCH, Weinheim, 2014, pp. 45-64.

8 M. A. Hannan, S. Mutashar, S. A. Samad and A. Hussain Biomed. Eng. OnLine, 2014, 13, 1-23.

9 Y.-M. Choi, M. G. Lee and Y. Jeon, Energies, 2017, 10, 1483.

10 Z. Lou, L. Li, L. Wang and G. Shen, Small, 2017, 13, 1701791.

11 S. Cosnier, A. J. Gross, A. Le Goff and M. Holzinger, J. Power Sources, 2016, 325, 252-263.

12 K. Dong, B. Jia, C. Yu, W. Dong, F. Du and H. Liu, Biosens. Bioelectron., 2013, 41, 916-919.

13 Y. Han, C. Yu and H. Liu, Biosens. Bioelectron., 2010, 25, 21562160.

14 M. Taghavi, A. Stinchcombe, J. Greenman, V. Mattoli, L. Beccai, B. Mazzolai, C. Melhuish and I. A. leropoulos, Bioinspir. Biomim., 2015, 11, 016001.

15 A. J. Bandodkar, J. Electrochem. Soc., 2017, 164, H3007H3014.

16 M. Gamella, A. Koushanpour and E. Katz, Bioelectrochemistry, 2018, 119, 33-42.

17 P. Cinquin, C. Gondran, F. Giroud, S. Mazabrard, A. Pellissier, F. Boucher, J.-P. Alcaraz, K. Gorgy, F. Lenouvel, S. Mathe, P. Porcu and S. Cosnier, PloS One, 2010, 5, e10476.

18 E. Katz, in Implantable Bioelectronics, Wiley-VCH, Weinheim, 2014, pp. 363-379.

19 E. Katz and K. MacVittie, Energy Environ. Sci., 2013, 6, 27912803.

20 C. Santoro, C. Arbizzani, B. Erable and I. leropoulos, J. Power Sources, 2017, 356, 225-244.

21 R. D. Milton and S. D. Minteer, J. R. Soc. Interface, 2017, 14, 20170253

22 P. K. Robinson, Essays Biochem., 2015, 59, 1-41.
23 R. A. S. Luz, A. R. Pereira, J. C. P. de Souza, F. C. P. F. Sales and F. N. Crespilho, ChemElectroChem, 2014, 1, 1751-1777.

24 A. Le Goff, M. Holzinger and S. Cosnier, Cell. Mol. Life Sci., 2015, 72, 941-952.

25 H. Sakai, T. Nakagawa, Y. Tokita, T. Hatazawa, T. Ikeda, S. Tsujimura and K. Kano, Energy Environ. Sci., 2009, 2, 133-138.

26 S. Tsujimura, H. Tatsumi, J. Ogawa, S. Shimizu, K. Kano and T. Ikeda, J. Electroanal. Chem., 2001, 496, 69-75.

27 A. Christenson, S. Shleev, N. Mano, A. Heller and L. Gorton, Biochim Biophys Acta, 2006, 1757, 1634-1641.

28 O. Courjean, F. Gao and N. Mano, Angew. Chem. Int. Ed., 2009, 48, 5897-5899.

29 A. Prévoteau, O. Courjean and N. Mano, Electrochem. Commun., 2010, 12, 213-215.

30 P. Kavanagh and D. Leech, Phys. Chem. Chem. Phys., 2013, 15, 4859-4869.

31 M. Rasmussen, S. Abdellaoui and S. D. Minteer, Biosens. Bioelectron., 2016, 76, 91-102.

32. S. Cosnier, M. Holzinger and A. Le Goff, Front. Bioeng. Biotechnol., 2014, 2, 45.

33. A. Karimi, A. Othman, A. Uzunoglu, L. Stanciu and S. Andreescu, Nanoscale, 2015, 7, 6909-6923.

34 H. Funabashi, S. Takeuchi and S. Tsujimura, Sci. Rep., 2017, 7, 45147.

35 A. Trifonov, K. Herkendell, R. Tel-Vered, M. Woerner and I. Willner, ACS Nano, 2013, 7, 11358-11368.

36 Y. Sugimoto, Y. Kitazumi, O. Shirai and K. Kano, Electrochemistry, 2017, 85, 82-87.

37 C. Zhao, P. Gai, R. Song, Y. Chen, J. Zhang and J-J. Zhu, Chem. Soc. Rev., 2017, 46, 1545-1564.

38 P. O. Saboe, E. Conte, M. Farell, G. C. Bazan and M. Kumar, Energy Environ. Sci., 2017, 10, 14-42.

$39 \mathrm{H}$. Funabashi, K. Murata and S. Tsujimura, Electrochemistry, 2015, 83, 372-375.

40. A. J. Gross, X. Chen, F. Giroud, C. Abreu, A. Le Goff, M. Holzinger and S. Cosnier, ACS Catal., 2017, 7, 4408-4416.

41. L. Halámková, J. Halámek, V. Bocharova, A. Szczupak, L. Alfonta and E. Katz, J. Am. Chem. Soc., 2012, 134, 5040-5043.

42. C. Meng, C. Liu and S. Fan, Electrochem. Commun., 2009, 11, 186-189.

43. R. Soni, B. Anothumakkool and S. Kurungot, ChemElectroChem, 2016, 3, 1329-1336.

44. U. Vohrer, I. Kolaric, M. H. Haque, S. Roth and U. DetlaffWeglikowska, Carbon, 2004, 42, 1159-1164.

45. P.-J. Cottinet, C. Souders, S.-Y. Tsai, R. Liang, B. Wang and C. Zhang, Phys. Lett. A, 2012, 376, 1132-1136.

46. R. H. Baughman, C. Cui, A. A. Zakhidov, Z. Iqbal, J. N. Barisci, G. M. Spinks, G. G. Wallace, A. Mazzoldi, D. De Rossi, A. G. Rinzler, O. Jaschinski, S. Roth and M. Kertesz, Science, 1999, 284, 1340 .

47. W. Zhu, J. P. Zheng, R. Liang, B. Wang, C. Zhang, G. Au and E. J. Plichta, Electrochem. Commun., 2010, 12, 1654-1657.

48. W. Zhu, D. Ku, J. P. Zheng, Z. Liang, B. Wang, C. Zhang, S. Walsh, G. Au and E. J. Plichta, Electrochim. Acta, 2010, 55, 2555-2560.

49. I. Mustafa, I. Lopez, H. Younes, R. A. Susantyoko, R. A. Al-Rub and S. Almheiri, Electrochim. Acta, 2017, 230, 222-235.

50. S.-H. Chung, C.-H. Chang and A. Manthiram, Small, 2016, 12, 939-950.

51. Y. Li, K. Huang and Y. Xing, Electrochim. Acta, 2012, 81, 20-24.

52. C.-W. Ma, L.-S. Hsu, J.-C. Kuo and Y.-J. Yang, Sens. ActuatorPhys., 2015, 231, 21-27. 
53. Y. Zhang, Y. Wang, J. Yu, L. Chen, J. Zhu and Z. Hu, RSC Adv., 2014, 4, 35904-35913.

54. H. Papa, M. Gaillard, L. Gonzalez and J. Chatterjee, Biosensors, 2014, 4, 449-460.

55. T. Leng and H. A. Fishman, Ophthalmic Surg. Lasers Imaging Retina, 2013, 44, 73-76.

56. S. M. Cooper, H. F. Chuang, M. Cinke, B. A. Cruden and M. Meyyappan, Nano Lett., 2003, 3, 189-192.

57. A. A. Alshahrani, H. Al-Zoubi, L. D. Nghiem and M. in het Panhuis, Desalination, 2017, 418, 60-70.

58. Y. Tang, J. Gou and Y. Hu, Polym. Eng. Sci., 2013, 53, 10211030.

59. J. G. Park, J. Louis, Q. Cheng, J. Bao, J. Smithyman, R. Liang, B. Wang, Chuck Zhang, J. S. Brooks, L. Kramer, P. Fanchasis and D. Dorough, Nanotechnology, 2009, 20, 415702.

60. J. Y. Oh, S. J. Yang, J. Y. Park, T. Kim, K. Lee, Y. S. Kim, H. N. Han and C. R. Park, Nano Lett., 2015, 15, 190-197.

61. C. W. N. Villarrubia, F. Soavi, C. Santoro, C. Arbizzani, A. Serov, S. Rojas-Carbonell, G. Gupta and P. Atanassov, Biosens. Bioelectron., 2016, 86, 459-465.

62. G. Strack, H. R. Luckarift, R. Nichols, K. Cozart, E. Katz and G. R. Johnson, Chem. Commun., 2011, 47, 7662-7664.

63. J. Chatterjee, J. Cardenal and A. Shellikeri, J. Biomed. Nanotechnol., 2015, 11, 150-156.

64. A. Ahmadalinezhad, G. Wu and A. Chen, Biosens. Bioelectron., 2011, 30, 287-293.

65. A. Baingane and G. Slaughter, Energies, 2017, 10, 1582.

66. F. Hennrich, S. Lebedkin, S. Malik, J. Tracy, M. Barczewski, H. Rösner and M. Kappes, Phys. Chem. Chem. Phys., 2002, 4, 2273-2277.

67. L. Hussein, G. Urban and M. Krueger, Phys. Chem. Chem. Phys., 2011, 13, 5831-5839.

68. H. W. Kroto, J. R. Heath, S. C. O'Brien, R. F. Curl and R. E. Smalley, Nature, 1985, 318, 162-163.

69. A. G. Rinzler, J. Liu, H. Dai, P. Nikolaev, C. B. Huffman, F. J. Rodríguez-Macías, P. J. Boul, A. H. Lu, D. Heymann, D. T. Colbert, R. S. Lee, J. E. Fischer, A. M. Rao, P. C. Eklund and R. E. Smalley, Appl. Phys. A, 1998, 67, 29-37.

70. D. Wang, P. Song, C. Liu, W. Wu and S. Fan, Nanotechnology, 2008, 19, 075609.

71. M. Zhang, S. Fang, A. A. Zakhidov, S. B. Lee, A. E. Aliev, C. D. Williams, K. R. Atkinson and R. H. Baughman, Science, 2005, 309, 1215-1219.

72. K. Yang, Z. Yi, Q. Jing, R. Yue, W. Jiang and D. Lin, Chin. Sci. Bull., 2013, 58, 2082-2090.

73 R. L. D. Whitby, T. Fukuda, T. Maekawa, S. L. James and S. V. Mikhalovsky, Carbon, 2008, 46, 949-956.

74 J. G. Park, J. Smithyman, C.-Y. Lin, A. Cooke, A. W. Kismarahardja, S. Li, R. Liang, J. S. Brooks, C. Zhang and B. Wang, J. Appl. Phys., 2009, 106, 104310.

75 G. Horne and Z. Liang, US Pat., 20160177511A1, 2016.

76 L. Liu, Q. Yang and J. Shen, J. Nanomater., 2015, 1-9.

77 G. Trakakis, D. Tasis, J. Parthenios, C. Galiotis and K. Papagelis, Materials, 2013, 6, 2360-2371.

78 J. DeGraff, R. Liang, M. Q. Le, J.-F. Capsal, F. Ganet and P.-J. Cottinet, Mater. Des., 2017, 133, 47-53.

79 M. Endo, H. Muramatsu, T. Hayashi, Y. A. Kim, M. Terrones and M. S. Dresselhaus, Nature, 2005, 433, 476-476.

80 I.-W. P. Chen, R. Liang, H. Zhao, B. Wang and C. Zhang, Nanotechnology, 2011, 22, 485708.

81 Y. Li and M. Kroeger, Carbon, 2012, 50, 1793-1806.
82 K. Yang, J. He, P. Puneet, Z. Su, M. J. Skove, J. Gaillard, T. M. Tritt and A. M. Rao, J. Phys.-Condens. Matter, 2010, 22, 334215.

83 J. P. Young, MSc thesis, Florida State University, 2009.

84 S. Wang, D. Haldane, R. Liang, J. Smithyman, C. Zhang and B. Wang, Nanotechnology, 2013, 24, 015704.

85 A. J. Gross, M. P. Robin, Y. Nedellec, R. K. O'Reilly, D. Shan and S. Cosnier, Carbon, 2016, 107, 542-547.

86 M. Bourourou, K. Elouarzaki, M. Holzinger, C. Agnès, A. Le Goff, N. Reverdy-Bruas, D. Chaussy, M. Party, A. Maaref and S. Cosnier, Chem. Sci., 2014, 5, 2885-2888.

87 A. Ansón-Casaos, J. M. González-Domínguez, E. Terrado and M. T. Martínez, Carbon, 2010, 48, 1480-1488.

88 M. J. Rahman and T. Mieno, J. Nanomater., 2014, 1-9.

89 P. R. Marcoux, P. Hapiot, P. Batail and J. Pinson, New J. Chem., 2004, 28, 302-307.

90 J. L. Bahr, J. P. Yang, D. V. Kosynkin, M. J. Bronikowski, R. E. Smalley and J. M. Tour, J. Am. Chem. Soc., 2001, 123, 65366542 .

91 B. Jousselme, G. Bidan, M. Billon, C. Goyer, Y. Kervella, S. Guillerez, E. A. Hamad, C. Goze-Bac, J.-Y. Mevellec and S. Lefrant, J. Electroanal. Chem., 2008, 621, 277-285.

92 M. M. Chehimi, Ed., Aryl Diazonium Salts: New Coupling Agents and Surface Science, Wiley-VCH, Weinheim, 2012.

93 Q. Zou, L. L. Kegel and K. S. Booksh, Anal. Chem., 2015, 87, 2488-2494.

94 F. Tasca, W. Harreither, R. Ludwig, J. J. Gooding and L. Gorton, Anal. Chem., 2011, 83, 3042-3049.

95 K. Elouarzaki, M. Bourourou, M. Holzinger, A. Le Goff, R. S. Marks and S. Cosnier, Energy Environ. Sci., 2015, 8, 20692074.

96 F. Giroud and S. D. Minteer, Electrochem. Commun., 2013, 34 157-160.

97 C. W. N. Villarrubia, K. Artyushkova, S. O. Garcia and P. Atanassov, J. Electrochem. Soc., 2014, 161, H3020-H3028.

98 J.Choi, Thin Solid Films, 2018, 651, 77-84

99 X.Chen, A. J. Gross, F. Giroud, M. Holzinger and S. Cosnier Electroanalysis, 2018, in press.

100 B. Reuillard, J. Warnan, J. J. Leung, D. W. Wakerley and E. Reisner, Angew. Chem.Int. Ed., 2016, 55, 3952-3957.

101 S. Roy, V. Jain, R. Bajpai, P. Ghosh, A. S. Pente, B. P. Singh and D. S. Misra, J. Phys. Chem. C, 2012, 116, 19025-19031.

102 X. Yang, J. Lee, L. Yuan, S.-R. Chae, V. K. Peterson, A. I. Minett, Y. Yin and A. T. Harris, Carbon, 2013, 59, 160-166.

103 C. W. N. Villarrubia, S. O. Garcia, C. Lau and P. Atanassov, ECS J. Solid State Sci. Technol., 2013, 2, M3156-M3159.

104 G. Strack, S. Babanova, K. E. Farrington, H. R. Luckarift, P. Atanassov and G. R. Johnson, J. Electrochem. Soc., 2013, 160, G3178-G3182.

105 S. Dinicola, M. G. Masiello, S. Proietti, P. Coluccia, G. Fabrizi, A. Palombo, F. Micciulla, S. Bistarelli, G. Ricci, A. Catizone, G. De Toma, M. Bizzarri, S. Bellucci and A. Cucina, Toxicol. Vitro Int. J. Publ. Assoc. BIBRA, 2015, 29, 1298-1308.

106 O. Zeni, A. Sannino, S. Romeo, F. Micciulla, S. Bellucci and M. R. Scarfi, Nanomed., 2015, 10, 351-360.

107 Z. Li and Z. Liang, Sci. Rep., 2017, 7, 42423.

108 F. Giroud, K. Sawada, M. Taya and S. Cosnier, Biosens. Bioelectron., 2017, 87, 957-963.

109 A. Zebda, S. Cosnier, J.-P. Alcaraz, M. Holzinger, A. Le Goff, C. Gondran, F. Boucher, F. Giroud, K. Gorgy, H. Lamraoui and P. Cinquin, Sci. Rep., 2013, 3, 1516. 
110 S. Sakurai, F. Kamada, D. N. Futaba, M. Yumura and K. Hata, Nanoscale Res. Lett., 2013, 8, 546.

111 B. Ashrafi, K. Laqua, Y. Martinez-Rubi, M. Jakubinek, B. Simard and D. P. and K, Proc. Am. Soc. Compos. Thirty-First Tech. Conf. 2016.

112 N. Lalaoui, A. Le Goff, M. Holzinger and S. Cosnier, Chem. Eur. J., 2015, 21, 16868-16873.

113 A. A. Arrocha, U. Cano-Castillo, S. A. Aguila and R. VazquezDuhalt, Biosens. Bioelectron., 2014, 61, 569-574.

114 M. T. Meredith, M. Minson, D. Hickey, K. Artyushkova, D. T. Glatzhofer and S. D. Minteer, ACS Catal., 2011, 1, 1683-1690.

115 C. W. N. Villarrubia, R. A. Rincon, V. Davis and P. Atanassov, ACS Appl. Mater. Interfaces, 2011, 3, 2402-2409.

116 C. W. N. Villarrubia, C. Lau, G. P. M. K. Ciniciato, S. O. Garcia, S. S. Sibbett, D. N. Petsev, S. Babanova, G. Gupta and P. Atanassov, Electrochem. Commun., 2014, 45, 44-47.

117 D. Bruen, C. Delaney, L. Florea and D. Diamond, Sensors, 2017, 17, E1866.

118 H. Lee, C. Song, Y. S. Hong, M. S. Kim, H. R. Cho, T. Kang, K. Shin, S. H. Choi, T. Hyeon and D.-H. Kim, Sci. Adv., 2017, 3, e1601314.

119 M. Onor, S. Gufoni, T. Lomonaco, S. Ghimenti, P. Salvo, F. Sorrentino and E. Bramanti, Anal. Chim. Acta, 2017, 989, 8087.

120 A. G. Antoshechkin, Alcohol Alcohol, 2001, 36, 608-608.

121 L. E. Nagy, Ed., Alcohol: Methods and Protocols, Humana Press, New York, 2008

122 R. C. Reid, S. D. Minteer and B. K. Gale, Biosens. Bioelectron., 2015, 68, 142-148.

123 N. Lalaoui, N. Means, C. Walgama, A. Le Goff, M. Holzinger, S. Krishnan and S. Cosnier, ChemElectroChem, 2016, 3, 20582062.

124 A. Szczupak, J. Halámek, L. Halámková, V. Bocharova, L. Alfonta and E. Katz, Energy Environ. Sci., 2012, 5, 8891-8895.

125 J. A. Castorena-Gonzalez, C. Foote, K. MacVittie, J. Halamek, L. Halamkova, L. A. Martinez-Lemus and E. Katz, Electroanalysis, 2013, 25, 1579-1584.

126 K. MacVittie, J. Halámek, L. Halámková, M. Southcott, W. D. Jemison, R. Lobel and E. Katz, Energy Environ. Sci., 2013, 6, 81-86.

127 M. Southcott, K. MacVittie, J. Halámek, L. Halámková, W. D. Jemison, R. Lobel and E. Katz, Phys. Chem. Chem. Phys., $2013,15,6278-6283$.

128 K. MacVittie, T. Conlon and E. Katz, Bioelectrochemistry, 2015, 106, 28-33.

129 I. W. Schubart, G. Göbel and F. Lisdat, Electrochim. Acta, 2012, 82, 224-232.

130 S. Ferri, K. Kojima and K. Sode, J. Diabetes Sci. Technol., 2011, 5, 1068.

131 N. Yuhashi, M. Tomiyama, J. Okuda, S. Igarashi, K. Ikebukuro and K. Sode, Biosens. Bioelectron., 2005, 20, 2145-2150.

132 R. D. Milton, F. Giroud, A. E. Thumser, S. D. Minteer and R. C. T. Slade, Chem. Commun., 2014, 50, 94-96.

133 R. D. Milton, F. Giroud, A. E. Thumser, S. D. Minteer and R. C. T. Slade, Electrochim. Acta, 2014, 140, 59-64.

134 G. Göbel, M. L. Beltran, J. Mundhenk, T. Heinlein, J. Schneider and F. Lisdat, Electrochim. Acta, 2016, 218, 278-284.

135 V. Scherbahn, M. T. Putze, B. Dietzel, T. Heinlein, J. J. Schneider and F. Lisdat, Biosens. Bioelectron., 2014, 61, 631638.

136 N. Loew, W. Tsugawa, D. Nagae, K. Kojima and K. Sode, Sensors, 2017, 17, 2636.
137 M. N. Zafar, N. Beden, D. Leech, C. Sygmund, R. Ludwig and L. Gorton, Anal. Bioanal. Chem., 2012, 402, 2069-2077.

138 C. Hou and A. Liu, Electrochim. Acta, 2017, 245, 303-308.

139 Y. Yu, J. Zhai, Y. Xia and S. Dong, Nanoscale, 2017, 9, 1184611850.

140 C. Abreu, Y. Nedellec, A. J. Gross, O. Ondel, F. Buret, A. Le Goff, M. Holzinger and S. Cosnier, ACS Appl. Mater. Interfaces, 2017 9, 23836-23842.

141 A. Zebda, C. Gondran, A. Le Goff, M. Holzinger, P. Cinquin and S. Cosnier, Nat. Commun., 2011, 2, 370.

142 M. Falk, Z. Blum and S. Shleev, Electrochim. Acta, 2012, 82, 191-202.

143 N. Mano and L. Edembe, Biosens. Bioelectron., 2013, 50, 478485

144 M. C. Weigel, E. Tritscher and F. Lisdat, Electrochem. Commun., 2007, 9, 689-693.

145 W. Zheng, Q. Li, L. Su, Y. Yan, J. Zhang and L. Mao, Electroanalysis, 2006, 18, 587-594.

146 K. Karnicka, K. Miecznikowski, B. Kowalewska, M. Skunik, M. Opallo, J. Rogalski, W. Schuhmann and P. J. Kulesza, Anal. Chem., 2008, 80, 7643-7648.

147 L. Hussein, S. Rubenwolf, F. von Stetten, G. Urban, R. Zengerle, M. Krueger and S. Kerzenmacher, Biosens. Bioelectron., 2011, 26, 4133-4138.

148 L. Hussein, Y. J. Feng, N. Aonso-Vante, G. Urban and M. Krueger, Electrochim. Acta, 2011, 56, 7659-7665.

149 S. Rubenwolf, S. Sané, L. Hussein, J. Kestel, F. von Stetten, G. Urban, M. Krueger, R. Zengerle and S. Kerzenmacher, Appl. Microbiol. Biotechnol., 2012, 96, 841-849.

150 G. P. M. K. Ciniciato, C. Lau, A. Cochrane, S. S. Sibbett, E. R. Gonzalez and P. Atanassov, Electrochim. Acta, 2012, 82, 208213

151 D. V. Pankratov, Y. S. Zeifman, O. V. Morozova, G. P. Shumakovich, I. S. Vasil'eva, S. Shleev, V. O. Popov and A. I. Yaropolov, Electroanalysis, 2013, 25, 1143-1149.

152 M. B. Abelson, I. J. Udell and J. H. Weston, Arch Ophthalmol, 1981, 99, 301

153 M. Sosna, J.-M. Chrétien, J. D. Kilburn and P. N. Bartlett, Phys. Chem. Chem. Phys., 2010, 12, 10018-10026.

154 S. Cosnier, R. Haddad, D. Moatsou and R. K. O'Reilly, Carbon, 2015, 93, 713-718.

155 C. F. Blanford, R. S. Heath and F. A. Armstrong, Chem. Commun., 2007, 0, 1710-1712.

156 Y. Umasankar, D. B. Brooks, B. Brown, Z. Zhou and R. P. Ramasamy, Adv. Energy Mater., 2014, 4, 1301306.

157 O. Fokina, J. Eipper, L. Winandy, S. Kerzenmacher and R. Fischer, Bioresour. Technol., 2015, 175, 445-453.

158 T. Miyake, K. Haneda, N. Nagai, Y. Yatagawa, H. Onami, S. Yoshino, T. Abe and M. Nishizawa, Energy Environ. Sci., 2011, 4, 5008-5012.

159 C. Bunte, L. Hussein and G. A. Urban, J. Power Sources, 2014, 247, 579-586

160 Z. Blum, D. Pankratov and S. Shleev, Expert Rev. Ophthalmol., 2014, 9, 269-273.

161 M. Scott, N. Y. Times, accessed January 2018.

162 M. Falk, V. Andoralov, Z. Blum, J. Sotres, D. B. Suyatin, T. Ruzgas, T. Arnebrant and S. Shleev, Biosens. Bioelectron., 2012, 37, 38-45.

163 G. Chen, H. Ghaed, R. U. Haque, M. Wieckowski, Y. Kim, G. Kim, D. Fick, D. Kim, M. Seok, K. Wise, D. Blaauw and D. Sylvester, in IEEE International Solid-State Circuits Conference, San Francisco, 2011. 
164 K. Sode and K. Mori, US Pat., 8999691B2, 2015.

165 Y. Liu, Y. Zhao, B. Sun and C. Chen, Acc. Chem. Res., 2013, 46, 702-713.

166 J.-P. Boutrand, Ed., Biocompatibility and Performance of Medical Devices, Woodhead Publishing, Cambridge, 2012.

167 S. Bellucci, M. Chiaretti, A. Cucina, G. A. Carru and A. I. Chiaretti, Nanomed., 2009, 4, 531-540.

168 A. Martinelli, G. A. Carru, L. D’llario, F. Caprioli, M. Chiaretti, F. Crisante, I. Francolini and A. Piozzi, ACS Appl. Mater.

Interfaces, 2013, 5, 4340-4349 